
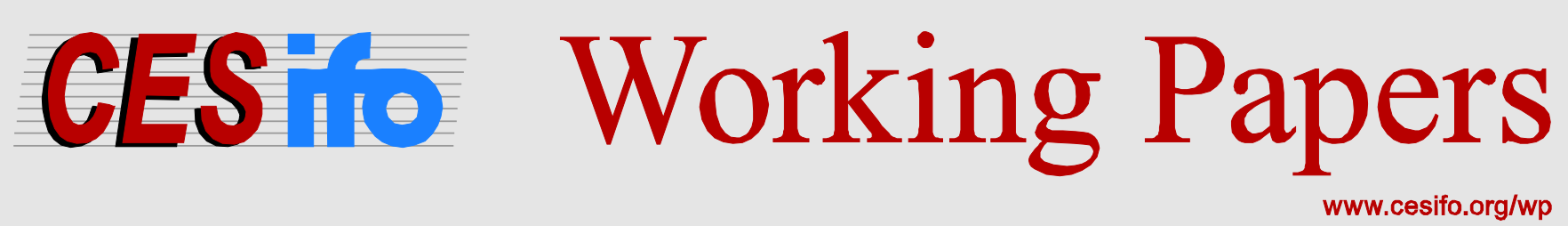

\title{
Evaluating the Effects of ACE Systems on Multinational Debt Financing and Investment
}

\author{
Shafik Hebous \\ Martin Ruf
}

CESIFO WORKING PAPER NO. 5360

CATEGORY 1: PUBLIC FINANCE

MAY 2015

Presented at CESifo Area Conference on Public Sector Economics, April 2015

An electronic version of the paper may be downloaded

- from the SSRN website:

- from the RePEc website:

- from the CESifo website:

www.SSRN.com

www.RePEc.org

www.CESifo-group.org/wp 


\title{
Evaluating the Effects of ACE Systems on Multinational Debt Financing and Investment
}

\begin{abstract}
Theory recommends aligning the tax treatment of debt and equity. A few countries, notably Belgium, have introduced an allowance for corporate equity (ACE) to achieve tax neutrality. We study the effects of adopting an ACE on debt financing, passive investment, and active investment of multinational firms, using high-quality administrative data on virtually all German-based multinationals. We use two main identification strategies, based on: (1) synthetic control methods, and (2) variations across affiliates within the multinational group. Our results suggest that an ACE reduces the corporate debt ratio of multinational affiliates. Additionally, an ACE increases intra-group lending and other forms of passive investment but has no effects on production investment of multinational affiliates. The findings indicate that a unilateral implementation of an ACE system generates a tax planning opportunity using a structure combining the benefits from the ACE with interest deductions.
\end{abstract}

JEL-Code: H250, F230.

Keywords: ACE, financial structure, corporate taxation, debt bias, multinational firms.

Shafik Hebous

Goethe University Frankfurt

Frankfurt / Germany

hebous@wiwi.uni-frankfurt.de

\author{
Martin Ruf \\ University of Tübingen \\ Tübingen / Germany \\ martin.ruf@uni-tuebingen.de
}

May 13, 2015

We thank the research centre staff of the Deutsche Bundesbank, particularly Heinz Herrmann and Simone Schultz, for their kind support. We received helpful comments from Johannes Voget, Alfons Weichenrieder, Andrea Pagano, Nadine Riedel, and seminar and conferences participants at the IMF, the OFS at the University of Oslo, the CESifo public sector economics area conference in Munich, ZEW Mannheim, and the Technical University Dortmund. The usual disclaimer applies. 


\section{Introduction}

A central debate in public economics and corporate finance is the role of tax incentives in triggering a debt bias in the corporate financial structure. Most tax systems around the world allow interest payments on loans to be deducted from the corporate tax base. In contrast, returns to equity typically do not benefit from tax deductions. As surveyed in de Mooij (2011), despite a variety of estimates and identification strategies, the empirical evidence indicates a higher reliance on debt financing in a high-corporate-tax environment.

The wedge between the tax treatments of equity and debt generates welfare losses and is frequently cited as affecting investment decisions. The debate on potentially tax-driven high corporate leverage gained new momentum in the aftermath of the global economic and financial crisis of 2008-2009, as several voices expressed concerns about firms' vulnerability to shocks and their potential macroeconomic consequences. ${ }^{1}$

As a policy response, many experts argue in favor of adopting a tax system that offers an allowance for corporate equity (ACE) to resolve tax discrimination against equity. In 2011, the Institute for Fiscal Studies published a high-profile report (Mirrlees et al., 2011) written by a number of experts under the chairmanship of James Mirrlees to "identify the characteristics of a good tax system for any open developed economy in the $21^{\text {st }}$ century". The Mirrlees Review concludes by recommending that countries adopt, inter alia, an ACE system. ${ }^{2}$ In the last two decades, a number of countries introduced a form of ACE: Austria, Belgium, Brazil, Croatia, Italy, Latvia, Portugal, and Liechtenstein.

Whilst countries' experiences may differ in the details, the core idea of an ACE system is to enable the deduction of "normal" returns to equity-financed investment at a measure of the opportunity cost of capital, e.g., the interest rate of long-term government bonds. Since the allowance is received with certainty, an ACE system taxes only the "abnormal" returns to investment.

Thus, ultimately, the idea of an ACE is not only to influence corporate debt policy but also to stimulate investment. Theoretically, offering an ACE achieves neutrality with respect to investment decisions, as it equates the before-tax with the after-tax payoff of the investment (Devereux and Freeman, 1991). Whether or not an ACE system does boost investment, as the theory predicts, is ultimately an empirical question.

In this study, we examine the effects of offering an ACE on corporate debt financing and investment using detailed administrative firm-level panel data on virtually all German firms

\footnotetext{
${ }^{1}$ For a discussion, see for example Keen, Klemm, and Perry (2010), de Mooij (2012), International Monetary Fund (2009), and European Commission (2012).

${ }^{2}$ See also Auerbach, Devereux, and Simpson (2010) and Griffith, Hines, and Sørensen (2010).
} 
investing abroad (the MiDi data). A key contribution of this study is that we explicitly distinguish between passive and active (production) investment. This distinction enables us to unveil a novel piece of evidence underscoring the fact that unilateral implementation of an ACE system creates tax planning opportunities for multinational firms. The plan is based on the strategic use of passive investment in the form of intra-group lending.

Specifically, equity injections in a multinational affiliate $X$ located in an ACE country can be passed on as lending to another group member $Y$ located in a different country with a high corporate income tax rate. For the group member $Y$, the interest on the loans is exempted from taxes and at the same time member $X$ benefits from the ACE relief in the ACE country. This form of investment is passive in that it does not involve increasing production or tangible assets.

The MiDi data are particularly suitable for examining the above type of double-dipping scheme, since we can observe the full ownership structure of the multinational group. We study intra-group lending by using information on the asset side of German investors abroad on loans to shareholders and affiliated enterprises with the parent.

Figure 1 reveals a compelling picture. In line with the tax plan outlined above, following the introduction of the Belgian ACE in 2006, Figure 1 shows a clear surge in the equityfinanced net lending of German investors in Belgium to their affiliated group members in other countries, reaching $€ 10$ billion (about 3 percent of Belgian GDP). ${ }^{3}$ There is a special interest in the experience of Belgium and the lessons that can be learned from the Belgian reform. Belgium adopted a hard version of ACE that treats the total book value of equity as the base of the allowance. In contrast, a soft ACE system, as in most of the other ACE countries, applies the ACE rate only to incremental (new) equity.

Although Figure 1 signals graphical evidence, one challenge facing the evaluation of macroeconomic policy changes in general and ACE reforms in particular is the lack of a coherent control group. The concern is that the evolution of leverage and investment, or the estimated effect, reflects not only the effect of ACE reforms, but also the effects of pre-reform differences in the determinants of leverage and investment across countries.

We address this issue by employing two different identification approaches, based on within-multinational-group comparisons and synthetic control methods. First, we examine whether or not there are differences between firms that operate under ACE systems and

\footnotetext{
${ }^{3}$ Although anti-avoidance measures, such as controlled foreign corporations (CFC) rules, are designed to preclude the use of passive investment as a tax planning strategy, they are typically not binding if the statutory corporate income tax rate of the foreign country exceeds a certain threshold. Hence, if a country implements an ACE system with a sufficiently high tax rate, then interest earnings circumvent the German CFC rules. For Belgium, the statutory corporate income tax rate was 33 percent, and is still currently higher than the rate for which the German CFC rules are binding (viz., 25 percent).
} 
their affiliated group members that are owned by the same parent company but located in countries without ACE systems. We estimate a variety of specifications. Including affiliate fixed effects can be viewed as taking account of parent-firm-destination-country effects that allow for unobserved affiliate and parent-firm heterogeneity. Simultaneously, this set of fixed effects allows all host-country time-invariant characteristics to have different effects across parent firms.

Second, we use synthetic control methods as developed in Abadie and Gardeazabal (2003) and Abadie, Diamond, and Hainmueller (2010). While our regression analysis mentioned above is useful in identifying an average effect and understanding heterogeneous aspects across firms, it is important to compare the ACE country with its counterfactual to address any remaining concerns about the interpretation of regression results and to obtain a countryspecific view. As synthetic control techniques require reasonably long time series before and after the treatment, the data enable us to apply this method to Belgium.

Our findings are summarized as follows. Regressions results suggest that an ACE reduces the total debt ratio by about 3 to 5 percentage points on average. We obtain similar results when we consider the ratio of loans from related parties. We find a positive effect on passive investment, but no effect on tangible investment. Results indicate that a hard ACE system is more effective in reducing corporate debt. We provide a battery of robustness checks and additional results that support these findings. For example, we conduct the analysis separately for large, small, and profitable firms. A hard ACE has often larger effects on the debt ratio than a soft one. Additionally, since in the case of Belgium the ACE applies only to corporations, we employ a difference-in-differences specification distinguishing between incorporated (treated) and non-incorporated (control) affiliates in Belgium.

Consistently with the regression results, the findings from the synthetic control method show that the average leverage ratio in Belgium fell below 45 percent following the implementation of the ACE. However, in the case of the synthetic control, this ratio remains very close to its previous decade level. Furthermore, for the synthetic control, equity-financed net lending has not increased as it did in Belgium in the period following the implementation of the ACE. This finding confirms the graphical evidence presented in Figure 1 indicating a tax plan by multinational firms combining the benefit from the ACE with interest deductions. It is also consistent with the idea of rechanneling loans again to Belgium as new equity injections to double the benefits from the same genuine new equity. This result is robust to a series of placebo studies on non-ACE countries. In addition, in line with the regression results, we find no effect of the Belgian ACE on investment in fixed assets of multinational affiliates.

Our findings have important implications. First, in spite of the success of a hard ACE in 
increasing capitalization, a more capitalized firm does not necessarily make higher production investments. Largely, the increase in equity injection is earmarked for intra-group lending and for benefiting from other sources of interest earnings. This speaks for accompanying ACE reforms with anti-avoidance provisions targeting intra-company transactions. Second, the results lend support to the notion of high gains from international tax coordination to diminish the use of a double-dipping international arrangements that combine an ACE with interest deductions or even generate a cascading of ACE benefits.

The paper proceeds as follows. In section 2, we relate our contribution to the existing literature. In section 3, we develop our hypotheses and provide a background briefly describing countries' experiences with ACE reforms. In section 4, we present the data. In section 5, we explain our identification approaches and present the results. Finally, we conclude in section 6 .

\section{Contribution to the Literature}

The idea of offering an ACE to achieve tax neutrality with respect to financing and investment decisions is certainly not new. The theoretical foundation of ACE systems was developed in the mid-1980s by Boadway and Bruce (1984), among others. The report by the Institute for Fiscal Studies Capital Taxes Group (IFS, 1991) also reached a similar conclusion to that of the The Mirrlees Review recommending offering an ACE.

Empirically, thus far, the effects of implementing ACE systems on the corporate financial structure and passive investment have not yet been extensively evaluated, perhaps due to the difficulty of accessing suitable data and also the above-outlined identification challenges.

Broadly, we add to the literature on the effects of corporate taxes on the financial structure. Most existing studies typically rely on cross-country or within-country variations in corporate income tax rates, whereas only a few papers exploit some form of quasi-natural experiment. Examples of studies include Desai, Foley, and Hines (2004) and Heider and Ljungqvist (forthcoming) for the US; Doidge and Dyck (2014) for Canada; and Huzinga, Laeven, and Nicodeme (2008) for Europe. ${ }^{4}$ In our research design, we exploit the introduction of ACE regimes as exogenous variations in the cost of debt.

Princen (2012) and Panier, Pérez-González, and Villanueva (2013) specifically address the issue of ACE. However, both studies focus only on corporate leverage and the ACE in Belgium. Due to the lack of a counterfactual, these authors consider firms in other European countries, e.g., France, as a control group. Arguably, this approach has shortcomings.

\footnotetext{
${ }^{4}$ For an earlier wave of empirical studies, see Gordon and Lee (2001) and Graham (2000, 2003).
} 
Our major contribution to this literature is in terms of contents and implemented identification strategies. First, we study not only the reaction of leverage, but also investment, and we consider not only Belgium, but also all other ACE countries. Importantly, we explicitly examine passive investment. This requires observing the ownership structure of the group, a distinctive feature of the MiDi database. This study is the first to use this dataset to address the topic of ACE and passive investment.

Second, at the methodological level, we use profound identification schemes. In our regression analysis, affiliates within the same multinational group arguably provide a more homogeneous environment for comparison than, e.g., comparing Belgian with French firms. Moreover, ACE reforms offer a natural application for synthetic control methods in which the comparison is between Belgium with an ACE regime and a hypothetical Belgium without the ACE.

In addition, our paper is related to a theoretical literature that uses computable general equilibrium (CGE) models to simulate the welfare effects of ACE regimes. De Mooij and Devereux (2011) find that an ACE reform would be welfare-improving for most EU members if it were coordinated at the European level. Keuschnigg and Dietz (2007) simulate a CGE model for Switzerland and propose an ACE reform that can increase GNP in the long run.

Finally, we contribute to the literature on tax planning of multinational firms. Wellknown tax loopholes and tax planning strategies typically involve tax havens or jurisdictions with low statutory corporate income tax rates (e.g., Dharmapala, 2008). The evidence in this paper discloses that a unilateral implementation of an ACE system opens the door for implementing a tax plan with a structure containing only "white-list" high-tax countries. ${ }^{5}$

\section{Hypothesis Development and Background}

\subsection{Hypothesis Development}

\subsubsection{ACE Reduces the Tax Benefits of Debt}

Since the seminal contributions by Modigliani and Miller (1958, 1963) and Miller (1977), it has been recognized that if taxes are not neutral, then the financial structure tends to be biased towards debt financing. Theoretically, allowing interest deductions can favor debt financing as governed by arbitrage conditions. Different models entail different details, but generally an arbitrage condition captures a trade-off between the non-tax costs of debt and

\footnotetext{
${ }^{5}$ Devereux (2012) discusses practical challenges in implementing an ACE regime within the current international tax system, pointing out profit-shifting opportunities for multinational companies.
} 
equity and the tax benefits of debt.

Examples of non-tax considerations are agency costs and default risks (e.g., Kraus and Litzenberger, 1973). The tax benefit of corporate debt can depend not only on the corporate income tax rate but also on other taxes such as the personal income tax. Often, however, international investors, such as pension funds and foreign portfolio investors, are exempted from the tax or at least not subjected to the full domestic tax rate (e.g., de Mooij, 2012).

The attractiveness of debt financing is reinforced in a multinational setup, since multinational firms can exploit differences across countries' corporate tax rates (Mintz and Weichenrieder, 2010). All in all, regardless of modeling details, the theory suggests that an increase in the corporate income tax rate, ceteris paribus, raises the tax benefits of corporate debt.

Devereux and Gerritsen (2010) and Devereux and Freeman (1991), among others, show that aligning the tax treatment of debt and equity by introducing an ACE reduces the tax benefit of debt. It eliminates the debt bias if it is applied with a rate equal to the interest rate used for serving the debt. Otherwise, the ACE lowers the debt bias but does not fully eliminate it. Theoretically, the rate of the ACE is set to be equal to the risk-free nominal interest rate. The rationale for this notional rate is based on the idea that the relief for equity is certain and therefore should be equal to the marginal cost of capital. A theoretical alternative according to Boadway and Bruce (1984) does not allow the deduction of interest payments. Instead, all returns to capital, regardless of the source of financing, receive an allowance equal to the risk-free rate.

Overall, offering an allowance for corporate equity, ceteris paribus, reduces discrimination against equity and hence lowers the corporate debt ratio.

\subsubsection{An ACE Increases Passive Investment}

Concerning the effects of an ACE on passive investment, a unilateral implementation of ACE generates an opportunity for the multinational group to implement a tax-minimizing strategy in a very similar vein to Altshuler and Grubert (2003) and Mintz and Weichenrieder (2010). The idea is an international arrangement according to which the affiliate in the low-tax country issues a loan to an affiliate in a high-tax country. For the lender affiliate, the returns to passive earnings enjoy the ACE, whereas the borrower affiliate deducts interest payments from the corporate tax base in the high-tax country.

In the model of Altshuler and Grubert (2003), instead of an ACE country, the lender affiliate is in a low-tax country in order to benefit from light taxation of interest earnings. However, in the presence of an ACE regime, returns on passive investment take advantage of the offered allowances without a need for a low corporate income tax rate. In fact, CFC 
rules in the home country of the ultimate owner might be binding if the lender affiliate is in a low-tax country. For instance, the German CFC rules apply if the foreign corporate income tax rate is below 25 percent. ${ }^{6}$ Therefore, an international structure combining ACE and interest deductions is particularly attractive if the ACE country is a relatively high-tax country, in order to avoid home country CFC rules.

To summarize, offering an ACE increases passive investment in the form of equity injection in affiliates in the ACE country to be forwarded as loans to affiliated group members in different countries. Yet, this tax plan does not necessarily imply cascading of ACE benefits in the sense of doubling the received allowance corresponding to the same initial genuine increase in equity. However, it is consistent with such a practice. If the borrower affiliate is located in a tax haven, for instance, it can forward the same loan again as an equity finance to affiliates in the ACE country. Such a practice is a frequently cited concern in connection with potential abuses of ACE systems, and in some ACE countries can be subjected to anti-avoidance measures (Zangari, 2014).

\subsubsection{ACE and Active Investment}

Taxation may cause investment projects that are worth undertaking before the tax to be unprofitable after the tax. Devereux and Freeman (1991), Bond and Devereux (1995), and Fane (1987) show that an ACE maintains neutrality in this respect, as returns are given relief up to a value equal to the cost of capital. Hence, only economic rents (abnormal returns) are taxed in such a system.

However, in many discussions, all investment is implicitly assumed to be production investment. Yet, there are reasons to think that an ACE does not necessarily increase investment in tangible assets. For example, a profitable strategy in the presence of an ACE can take the form of passive investment as described in the previous subsection.

Furthermore, in practice, ACE experiments tend to be associated with ongoing discussions generating uncertainty regarding their survival. As we will summarize below, most ACE regimes have eventually been abolished. For a firm, abolishing the ACE would immediately remove the tax benefits from using equity. This stands in stark contrast to other elements in the tax codes, such as depreciation allowances. For example, a long-term production investment that starts based on some depreciation allowance rules would not, in principle, be affected by subsequent changes in those rules.

Moreover, the presumed effect of tax neutrality on investment is based on remedying the distortion in the cost of capital. However, firms may incorrectly discount expected net cash

\footnotetext{
${ }^{6}$ Ruf and Weichenrieder (2012) describe the German CFC rules.
} 
flows. As emphasized in Bylow and Summers (1984) and Summers (1987), firms tend to use the after-tax cost of capital as a uniform discount rate without conditioning on the risk characteristics of future flows. Lund (2014) presents an extended model and shows that when firms use the same discount rate under any tax system, they undervalue projects under an ACE.

There are a number of theoretical papers that emphasize how an ACE system no longer achieves neutrality with respect to the size of investment in the presence of moral hazard and financial frictions (e.g., Hagen and Sannarnes, 2007, and Keuschnigg and Ribi, 2012). Agency problems complicate the maintenance of the neutrality property, for example, by altering managerial incentives and encouraging unproductive investment (Koethenbuerger and Stimmelmayr, 2014).

On the whole, the above discussion suggests that the effect of an allowance for corporate equity on multinational affiliates' investment in tangible assets is rather ambiguous.

\subsection{Background: Countries' Experiences with ACE Reforms}

In practice, the implementation of an ACE system entails resolving a number of issues, including the rate of $\mathrm{ACE}$ and the corresponding base. The main distinction, though, is the definition of the base. We follow Klemm (2007) in distinguishing between two classifications: A hard ACE regime considers the entire book value of equity as the base for computing the allowances, whereas a soft ACE regime treats only new (incremental) equity as the ACE base.

Table 1 lists countries that offer or offered an ACE, including the implementation periods. Table A1 in the appendix provides further details on the main fundamental elements of ACE reforms.

\subsubsection{Hard ACE}

Belgium applies the rate of the ACE to the book value of equity after adjusting for participation in other firms to avoid doubling the relief. The reform was implemented in 2006 and is currently still in place. The ACE rate is the 10-year government bond rate. It was about 4 percent in 2010. This means that equity of $€ 1$ million, for instance, receives an allowance of $€ 40,000$ that can be deducted from the tax base. Zangari (2014) presents an overview of the various aspects of the Belgian ACE. For example, Belgium does not embrace anti-avoidance provisions aiming at intra-firm borrowing and lending transactions.

Croatia adopted a hard ACE between 1994 and 2000. Keen and King (2002) describe the Croatian system in detail. Liechtenstein embraced an ACE system in 2011. The applicable 
rate is specified annually.

\subsubsection{Soft $\mathrm{ACE}$}

Austria applied an ACE starting from 2000 with a rate equal to the average return of government bonds in secondary markets plus $0.8 \mathrm{pp}$. The base includes only new equity. Eventually, Austria put an end to its ACE in 2004.

The Brazilian system allows the deduction of notional returns when they are paid out to shareholders. Klemm (2007) describes the Brazilian ACE system.

Italy offered a soft ACE between 1997 and 2003. The rate of ACE was 7 percent from 1997 to 2003, and 6 percent from 2001 to 2003. Again, Italy reinstalled an ACE regime in 2012. Currently, the rate is 4 percent. Zangari (2014) provides a detailed description of the Italian ACE. For instance, Italy adopt anti-avoidance provisions in connection with intra-firm transactions. Latvia implemented an ACE regime in 2009 with an allowance rate of 4.37 percent applied only to new equity. The Latvian ACE ended in 2014.

As shown in Table 1, Switzerland is among the countries that are considering introducing an ACE in the near future.

In most of the above countries, the implementation of ACE was heavily debated from the start. Offering an ACE is associated with a loss of tax revenues, as it implies, by definition, giving up a tax base. This factor impedes embracing ACE reforms and played a key role in abolishing them in some countries. As pointed out by de Mooij (2012), on average, an ACE entails a reduction of corporate tax revenues by about to 0.5 percent of GDP.

\section{Data}

According to the German Foreign Trade Regulation, German investors must report key balance sheet items such as sales, liabilities, and assets of their foreign subsidiaries. These data are confidential and stored at the headquarter of the Deutsche Bundesbank. Essentially, this database contains the whole population of German firms investing abroad, as the reporting requirements are generally met for all majority-owned affiliates with a total balance sheet exceeding $€ 3$ million. ${ }^{7}$ It is a distinctive feature of this database that we can observe the full ownership structure of the multinational group. That is, we observe all affiliates that belong to the same German parent firm, whether directly or indirectly held. This is a very valuable piece of information that we will use in our empirical identification strategy. Furthermore, we observe intra-group lending.

\footnotetext{
${ }^{7}$ See Lipponer (2009) for a detailed description of the data and reporting requirements.
} 
Interest income from raising capital and financial activities within the multinational group is deemed as passive income under the German tax code and hence might be subject to German taxes according to CFC rules. However, in the case of insurance firms and banks, this sort of income is regarded as active income. Therefore, our analysis focuses on non-financial corporations. Thus, our firm-level panel includes 208,573 affiliate observations stemming from 8,155 parent firms in the period from 1999 to 2011.

Table A2 in the appendix summarizes the variables used in our analysis, including mean values and standard deviations.

Debt We define two different leverage ratios. First, the total debt ratio is the ratio of total liabilities to total balance sheet. Second, the ratio of loans from affiliated enterprises is defined as the ratio of liabilities to shareholders and other affiliated parties linked with the subsidiary to total balance sheet. Figure 2 presents the mean values of debt ratios for the ACE countries. In Belgium, the average total debt ratio decreased in the ACE period. In Italy, for instance, the simple average debt ratio did not decline in the ACE period, probably because the allowance is only applied to new equity.

Investment We define two variables capturing passive investment. First, equity-financed net lending is equal to loans to affiliated enterprises minus total liability. Second, passive assets is defined as financial assets excluding shares in affiliated enterprises and loans to shareholders. Production (or active) investment is defined as the total of tangible and intangible assets.

Additional Firm-Level Variables Size is measured by the total balance sheet of the affiliate. Profitability is profits prior to profit distribution and offsetting of losses carried forward, divided by total equity (total balance sheet minus total liabilities). Tangibility is the ratio of total tangible and intangible assets to total assets (including financial, current, and other assets). Median industry leverage is an industry-specific variable defined as the median of the industry-specific leverage in each year.

Macroeconomic Variables We merge the MiDi data with an array of country-specific variables. We organize data on statutory corporate income tax rates by extending the dataset of Mintz and Weichenrieder (2010), using information from KPMG country reports. Figure 3 is a binned scatterplot of statutory corporate income tax rates and total debt ratios of affiliates abroad - i.e., plotting mean values of both variables within a bin. In line with a strategy of international debt shifting, we observe an upward-sloping relationship. High debt ratios are associated with high tax rates.

Standard macroeconomic variables are obtained from the World Bank World Development Indicators (WDI). These are inflation, PPP GDP (constant prices, 2005), and PPP GDP per capita (constant prices, 2005). Unemployment is as a percentage of the total labor force. 
Inflation is the annual percentage increase in consumer prices. Interest is the lending interest rate provided by the WDI and complemented by the long-term interest rate provided by the OECD. Additionally, as institutional measures, we use the Political Stability index of the World Bank Worldwide Governance Indicators (a higher value indicates higher stability) and the Corruption Perception index provided by Transparency International (a higher value indicates less corruption).

All level variables, except ratios, are expressed in natural logarithms. We winsorize ratios at the 1 percent level to eliminate extreme values.

\section{Empirical Assessment}

\subsection{Regression Analysis}

Consider the benchmark specification

$$
d_{e b t_{i k p t}}=\alpha_{0}+\alpha_{1} A C E_{k t}+\alpha_{2} T A X_{k t}+\boldsymbol{\Gamma} \boldsymbol{X}_{i k p t}+\boldsymbol{\Phi}_{i}+\boldsymbol{\lambda}_{t}+\varepsilon_{i k p t},
$$

where $d e b t_{i k p t}$ is a debt-equity ratio of affiliate $i$ operating in country $k$ owned by parent firm $p$ in year $t$.

The dummy $A C E_{k t}$ is defined as

$$
A C E_{k t}= \begin{cases}1 & \text { if a country implements an ACE system in year } t \\ 0 & \text { otherwise }\end{cases}
$$

We are interested in $\alpha_{1}$ and expect it to be negative. In addition, to allow for potential heterogeneity across the ACE systems, we define $A C E$ hard equal to 1 during the ACE periods of Belgium, Croatia, and Liechtenstein, and zero otherwise. ACE soft is equal to 1 during the ACE periods of Austria, Brazil, Italy, Latvia, and Portugal, and zero otherwise.

The coefficient $\alpha_{2}$ on the statutory corporate income tax rate $T A X_{k t}$ is expected to be positive, in line with Figure 3 and previous literature supporting a tax-motivated debt bias.

The vector $\boldsymbol{X}_{i k p t}$ includes a number of explanatory variables as suggested by Huizinga, Laeven, and Nicodeme (2008). These are affiliate-specific variables including size, tangibility, and profitability, and also country-specific variables including GDP growth, interest rate, political stability, and inflation. Further, following Frank and Goyal (2009), we add the median industry leverage to the set of explanatory variables.

The set of affiliate fixed effects $\left(\boldsymbol{\Phi}_{i}\right)$ captures unobserved heterogeneity across affiliates and additionally allows the time-invariant country-specific effects to have different effects across 
parent firms. That is, for example, distance from Germany to the host country can have different effects across German parent firms. Additionally, industry fixed effects are nested within the affiliate fixed effects, accounting for industry-specific characteristics. Furthermore, our specification includes year fixed effects $\boldsymbol{\lambda}_{t}$ to allow for global factors affecting all crosssectional units in a certain year. We estimate a number of variants of the above specification with different sets of fixed effects.

\subsubsection{Results: Debt Financing}

Table 2 presents benchmark estimation results. The dependent variable is the total debt ratio. All standard errors are clustered at the country-year level, correcting for potential correlation between the error terms within a country-year cell. In column (1), we start with a parsimonious specification including parent firm and year fixed effects, essentially comparing affiliates within the multinational group. The estimated coefficient on the ACE dummy suggests that ACE regimes reduce the total debt ratio by about 3.5 percentage points on average. Further, in line with the literature, the estimated marginal effect of the statutory corporate income tax rate suggests that an increase in the tax rate of 1 percentage point leads to an increase in the debt ratio of 0.35 percentage point.

In column (2), we restrain the ACE dummy to equal 1 only for hard versions of an ACE. The estimated coefficient on this dummy indicates that hard ACE systems lower the total debt ratio by about 5 percentage points on average. To get a feel for the magnitude, a calibrated theoretical model in Sørensen (2014) suggests that a reduction of about 5 percentage points in the debt ratio is needed in order to eliminate the excess burden of the tax distortion. In column (3), the ACE soft dummy identifies only soft ACE systems. The effect becomes smaller, suggesting a decrease in total debt ratio of 2.5 percentage points. In columns (4) to (7), we include affiliate fixed effects. These already capture country, industry, and parent fixed effects. As in the previous columns, the estimated coefficients on the ACE dummies are negative and significant. A soft version of an ACE in the last column has an insignificant coefficient, though, when we include both ACE dummies at the same time. Again, the estimated effect of the statutory corporate tax rate on the debt ratio is positive.

Table 3 shows the same specifications as in Table 2, but the dependent variable contains only loans from affiliated parties. In columns (1) to (7), all specifications yield negative effects of ACE variables on the ratio of loans from affiliated parties. Also, this intra-firm debt ratio is positively associated with corporate tax rates.

Table 4 presents a number of robustness checks. In the upper panel, we add lagged values of all control variables. In second panel, we add the lagged value of the total debt 
ratio. Additionally, in the third panel, since some parent firms can own more than one subsidiary in a country, we consolidate at the parent-firm-country-year level and use parentfirm-country pairs of fixed effects. In the fourth and fifth panels, we explicitly distinguish between small and large affiliates, based on the median of total balance sheet. In the sixth and seventh panels, we run regressions for highly profitable and less profitable affiliates separately. We obtain similar results across all these specifications. ACE regimes are associated with a significant negative coefficient. When we include $A C E$ hard and $A C E$ soft, the latter remains significant for small affiliates and in the sample of high-profit affiliates. ACE hard is significant in all specifications.

\subsubsection{Results: Investment}

Since equity-financed net lending at the firm level is frequently nonpositive, we employ three different specifications. First, we use passive assets as a broader variable capturing passive investment. The results are reported in columns (1) to (3) in Table 5. The estimated coefficient of 0.26 suggests that adopting an ACE increases passive assets by 29.6 percent $\left(e^{0.26}-1\right)$.

Second, we define a binary choice variable equal to 1 if the variable equity-financed net lending is larger than zero. Using this specification, we can estimate the effects of an ACE on the probability of being a net-lender affiliate. Columns (4) to (6) in Table 5 show the results. For example, in column (5), the estimated coefficient of 0.618 implies an odds ratio of 1.8, suggesting that adopting a hard ACE increases the odds of being a net-lender affiliate by a factor of 1.8 .

Third, we estimate a host country location choice model, as in Ruf and Weichenrieder (2012), by only looking at new affiliates. This model enables us to estimate the likelihood of a country's hosting a new affiliate with special financing functions (i.e., characterized by positive equity-financed net lending). The latent variable is coded 1 if a country hosts a new affiliate that has positive net equity-financed lending, and zero for the other countries. Columns (7) to (9) indicate that adopting an ACE increases the likelihood of locating a net-lender affiliate in the ACE country.

Regarding production investment, Table 6 shows that the corporate income tax rate has significant negative effects on fixed assets in all specifications. However, ACE variables have no significant effects on fixed assets; neither $A C E$ hard nor $A C E$ soft seems to affect investment in tangible assets. Considering the growth of production investment, instead of levels, also gives no significant effects (results are not reported). 


\subsubsection{Additional Results: Corporation vs. Non-corporation}

Before we proceed with using synthetic control methods, we can exploit one additional source for identification. Namely, in Belgium, the rate of ACE applies only to incorporated firms. As a further test, we consider non-incorporated affiliates as a within-country control group. As multinational affiliates mostly tend to be corporations, we find a small but reasonable number of non-incorporated affiliates in Belgium. Adding non-incorporated affiliates to the sample makes them constitute about 3 percent of total observations. Looking at these cases is informative. We specify a difference-in-differences model of the form

$$
y_{i t}=\beta_{0}+\beta_{1}\left(\text { incor }_{i} \times A C E_{t}\right)+\boldsymbol{\Phi}_{i}+\boldsymbol{\lambda}_{t}+\epsilon_{i t},
$$

where the outcome variable $y$ depicts debt or investment variables and the dummy incor ${ }_{i t}$ is equal to 1 if the affiliate is incorporated; zero otherwise.

The coefficient $\beta_{1}$ on the interaction term gives the average treatment effect. We note that multinational affiliates tend to stick to their legal forms. In the sample, there are only six cases of switching the legal form from or to corporations; these we discard. This observation is reassuring that potential selection in the treatment is not a major concern in this application. The set of affiliate fixed effects, $\boldsymbol{\Phi}_{i}$, captures affiliate-specific effects including the legal form incor $_{i}$. All Belgium-wide macroeconomic variables, such as taxes and $A C E_{t}$, are captured by the set of year fixed effects, $\boldsymbol{\lambda}_{t}$.

Table 7 supports the above regression results. Panel (a) shows that the Belgian ACE reduces the dabt ratio of incorporated affiliates in Belgium. Passive investment increases (panel (b) of Table 7), whereas the effect of the ACE on tangibles is insignificant (panel (c) of Table 7 ).

\subsection{Synthetic Control Method}

We are interested in constructing a counterfactual country that serves as a synthetic control with respect to that where the ACE was actually implemented. The aim is to make sure that the synthetic country mimics as closely as possible the actual one before the treatment. Then, we can compare the evolution of the variable of interest, $y$ (leverage or investment), in the two countries after the treatment. For example, the comparison between Belgium and the synthetic Belgium illustrates what would have happened had Belgium not installed an ACE in 2006.

Let $\mathbf{X}_{1}$ be a $K \times 1$ vector of variables that determines the outcome variable $y$ in the treated country, and $\mathbf{X}_{0}$ be a $K \times J$ matrix including their counterparts for the rest of the 
non-treated countries, $j=1,2, \ldots, J$. As in Abadie and Gardeazabal (2003) and Abadie, Diamond, and Hainmueller (2010), for constructing the synthetic control, we optimize over the weights $\mathbf{W}=\left(\omega_{1}, \ldots, \omega_{j}\right)^{\prime}$ associated with each possible control country $j$ to minimize the distance between $\mathbf{X}_{1}$ and $\mathbf{X}_{0} \mathbf{W}$ :

$$
\underset{\mathbf{W}}{\operatorname{argmin}}\left(\mathbf{X}_{\mathbf{1}}-\mathbf{X}_{\mathbf{0}} \mathbf{W}\right)^{\prime} \mathbf{V}\left(\mathbf{X}_{\mathbf{1}}-\mathbf{X}_{\mathbf{0}} \mathbf{W}\right)
$$

subject to $\sum \omega_{j}=1$ and $\omega_{j} \geq 0$.

The matrix $\mathbf{V}$ is diagonal positive semidefinite. Its elements give the relative importance of each predictor in $\mathbf{X}_{1}$. This method requires a reasonable pre-reform time series to credibly fit the treated outcome variable. We are able to apply it to Belgium. At the country-year level we can go back 11 years before the Belgian reform. ${ }^{8}$ We add distance between Germany and a host country to the set of predictors (in the regression analysis, its effect is captured by the affiliate fixed effects).

Figure 4 shows the results for the debt ratio. The optimal weights are positive for France (71.5\%), Denmark (6\%), Malta (22.1\%), and Uruguay (0.4\%). The average debt ratio of German affiliates in Belgium fell below 45 percent following the implementation of ACE. For the synthetic control, after the reform, this ratio remains at its 1990s level of around 60 percent.

From the regression analysis, the magnitude of the estimated average effect on the debt ratio obtained from benchmark specifications is about 4 to 5 percentage points. A countryspecific regression for Belgium (a before-after analysis) yields a larger effect of about 11 percentage points (results are not reported). This magnitude is similar to that illustrated by the synthetic control method. The difference between the panel regression analysis and synthetic control methods is due to comparing with different control groups. The multicountry regressions give the same weights for all affiliates within the multinational group, whereas the synthetic control is based on optimizing over the assigned weights to produce the counterfactual.

The upper panel of Figure 5 presents the results for equity-financed net lending. The optimal weights are positive for the Netherlands (60.5\%), France (17.5\%), Luxembourg (18.2\%), and Uruguay (3.9\%). There is a clear increase in equity-financed net lending in Belgium, but no indication that a similar increase occurs in the synthetic control. This finding supports the graphical evidence presented in the introduction. Also, it indicates that the combination

\footnotetext{
${ }^{8}$ For instance, in the case of Brazil there is no post-reform period in our firm-level sample. In the case of Latvia, there are only three post-reform years, and Italy abolished in 2003 its system that was introduced in 1997.
} 
of a high statutory corporate income tax rate and an ACE system enables a German multinational group to use intra-firm lending as an effective plan to minimize the group's tax bill in spite of the existence of CFC rules.

The lower panel of Figure 5 shows that investment in fixed assets in Belgium does not diverge from the synthetic control following the introduction of the ACE. Both the synthetic control and Belgium move fairly close to each other before and after the reform.

Finally, regarding inference, Abadie, Diamond, and Hainmueller (2010) suggest relying on a series of falsification tests. We conduct a set of placebo studies using potential control countries in the sample excluding the ACE countries (38 potential controls). How often would we obtain results of this magnitude if we had chosen a country at random for the study instead of Belgium? For each placebo run, we compute the distance between $\mathbf{X}_{1}$ and $\mathbf{X}_{0} \mathbf{W}$. The upper panel of Figure 6 considers equity-financed net lending and plots the gaps for placebo tests with mean squared prediction error (MSPE) not higher than twice the MSPE of Belgium. This test provides significant evidence that the magnitude estimated for net equity-financed lending in Belgium is unusually different from that for countries that did not implement an ACE system. The lower panel plots the gaps from a series of placebo tests for the debt ratio.

\section{Concluding Remarks}

Does an ACE reduce the corporate debt bias? If so, does that imply increases in investment? In this study, we have addressed these questions using a high-quality administrative database on German-based multinational firms. Results based on various specifications and identification strategies suggest that corporate debt decreases following an ACE, especially in its hard version. Furthermore, the findings indicate that the resulting higher capitalization of multinational affiliates is associated with increases in passive investment rather than production investment. An ACE opens the door for multinational firms to use an international tax plan. Lender affiliates receive the allowances on interest earnings, whereas borrower affiliates deduct interest payments or forward them back to the ACE country as a new equity injection.

Yet, this result is not to be taken as an argument against the theory of ACE per se, but rather as a hint to improve the practice of implementing an ACE. Practical aspects might include increasing the credibility of an ACE reform and the quality of its anti-avoidance provisions. Further research may disclose additional important evidence. 


\section{References}

Abadie, A., and Gardeazabal, L. (2003), The Economic Costs of Conflict: A Case Study of the Basque Country, American Economic Review 93(1), 112-132.

Abadie, A., Diamond, A., and Hainmueller, J. (2010), Synthetic Control Methods for Comparative Case Studies: Estimating the Effect of California's Tobacco Control Program, Journal of the American Statistical Association 105 (490), 493-505.

Altshuler, R., and Grubert, H. (2003), Repatriation Taxes, Repatriation Strategies and Multinational Financial Policy, Journal of Public Economics 87 (1), 73-107.

Auerbach, A., Devereux, M. P., and Simpson, H. (2010), Taxing Corporate Income, in Mirrlees, J. (Ed.), Dimensions of Tax Design, Chapter 9, 837-893, Oxford University Press, Oxford, UK.

Boadway, R., and Bruce, N. (1984), A General Proposition on the Design of a Neutral Business Tax, Journal of Public Economics 25, 231-239.

Bond, S., and Devereux, M.P. (1995), On the Design of a Neutral Business Tax under Uncertainty, Journal of Public Economics 58 (1), 57-71.

Bulow, J. I., and Summers, L. H. (1984), The Taxation of Risky Assets, Journal of Political Economy 92 (1), 20-39.

Dharmapala, D. (2008), What Problems and Opportunities Are Created by Tax Havens?, Oxford Review of Economic Policy 24 (4), 661-679.

de Mooij, R. (2011), The Tax Elasticity of Corporate Debt: A Synthesis of Size and Variations, IMF Working Paper No. 11/95.

de Mooij, R. (2012), Tax Biases to Debt Finance: Assessing the Problem, Finding Solutions, Fiscal Studies 33 (4), 489-512.

de Mooij, R., and Devereux, M. P. (2011), An Applied Analysis of ACE and CBIT Reforms in the EU, International Tax and Public Finance 18 (1), 93-120.

de Mooij, R., Keen, M., and Orihara, M. (2013), Taxation, Bank Leverage and Financial Crises, IMF Working Paper No. 13/48.

Desai, M. A., Foley, F. C., and Hines, J. R. (2004), A Multinational Perspective on Capital Structure Choice and Internal Capital Markets, Journal of Finance 59 (6), 2451-2487.

Devereux, M. P. (2012), Issues in the Design of Taxes on Corporate Profit, National Tax Journal 65 (3), 709-730. 
Devereux, M. P., and Gerritsen, A. (2010), The Tax Treatment of Debt and Equity, in D. Albergtse and P. Kavelaars (Eds.), Towards a European Profit Tax, Deventer, Kluwer, 67-74.

Devereux, M. P., and Freeman, H. (1991), A General Neutral Profits Tax, Fiscal Studies $12(3), 1-15$.

Doidge, C., and Dyck, A. (2014), Taxes and Corporate Policies: Evidence From a Quasi Natural Experiment, Journal of Finance.

European Commission (2012), The Debt-Equity Tax Bias: Consequences and Solutions, Taxation Paper No 33 (2012), European Commission, Brussels.

Fane, G. (1987), Neutral Taxation under Uncertainty, Journal of Public Economics 33 (1), 95-105.

Frank, M.Z., and Goyal, V.K. (2009), Capital Structure Decisions: Which Factors Are Reliably Important?, Financial Management 38 (1), 1-37.

Gordon, R. and Lee, Y. (2001), Do Taxes Affect Corporate Debt Policy? Evidence from U.S. Corporate Tax Return Data, Journal of Public Economics 82 (2), 195-224.

Graham, J.R. (2003), Taxes and Corporate Finance: A Review, Review of Financial Studies 16 (4), 1075-1129.

Graham, J.R. (2000), How Big Are the Tax Benefits of Debt?, Journal of Finance 55 (5), 1901-1941.

Griffith, R., Hines, J., and Sørensen P. B. (2010), International Capital Taxation, in Mirrlees, J. (Ed.) Dimensions of Tax Design, Chapter 10, 914-1027, Oxford University Press, Oxford, UK.

Hagen, K., and Sannarnes, J.G. (2007), Taxation of Uncertain Business Profits, Private Risk Markets and Optimal Allocation of Risk, Journal of Public Economics 91, $1507-1517$.

Heider, F., and Ljungqvist, A. (forthcoming), As Certain as Debt and Taxes: Estimating the Tax Sensitivity of Leverage from State Tax Changes, Journal of Financial Economics.

Huizinga, H., Laeven, L., and Nicodeme, G. (2008), Capital Structure and International Debt Shifting, Journal of Financial Economics 88 (1), 80-118.

IFS (1991), Equity for Companies: A Corporation Tax for the 1990s, Commentary 26, Institute for Fiscal Studies, London. 
International Monetary Fund (2009), Debt Bias and Other Distortions: Crisis-related Issues in Tax Policy, Washington DC.

Keen, M., and King, J. (2002), The Croatian Profit Tax: An ACE in Practice, Fiscal Studies 23 (3), 401-418.

Keen, M., Klemm, A., and Perry, V. (2010), Tax and the Crisis, Fiscal Studies 31 (1), $43-79$.

Klemm, A. (2007), Allowances for Corporate Equity in Practice, CESifo Economic Studies $53(2), 229-262$.

Kraus, A., and Litzenberger, R. (1973), A State-preference Model of Optimal Financial Leverage, Journal of Finance 28 (4), 911-922.

Keuschnigg, C., and Ribi, E. (2012), Profit Taxes and Financing Constraints, International Tax and Public Finance 20 (5), 808-882.

Keuschnigg, C., and Dietz, M. D. (2007), A Growth Oriented Dual Income Tax, International Tax and Public Finance 14 (2), 191-221.

Koethenbuerger, M., and Stimmelmayr, M. (2014), Corporate Deductibility Provisions and Managerial Incentives, Journal of Public Economics 111, 120-130.

Lipponer, A. (2011), Microdatabase Direct Investment - MiDi. A Brief Guide, Technical Documentation, Deutsche Bundesbank, Frankfurt.

Lund, D. (2014), How Taxes on Firms Reduce the Risk of After-tax Cash Flows, FinanzArchiv / Public Finance Analysis 70 (4), 567-598.

Miller, M. H. (1977), Debt and Taxes, Journal of Finance 32 (2), 261-275.

Modigliani, F., and Miller, M. H. (1963), Corporate Income Taxes and the Cost of Capital: A Correction, American Economic Review 53 (3), 433-443.

Modigliani, F., and Miller, M. H. (1958), The Cost of Capital, Corporate Finance and the Theory of Investment, American Economic Review 48 (3), 261-97.

Mintz, J. and Weichenrieder, A. (2010), The Indirect Side of Direct Investment: Multinational Company Finance and Taxation, MIT Press, Cambridge, MA.

Mirrlees, J., Adam, S., Besley, T., Blundell, R., Bond, S., Chote, R., Gammie, M., Johnson, P., Myles, G., and Poterba, J. (2011), Tax by Design: The Mirrlees Review, Oxford University Press, Oxford, UK.

Panier, Pérez-González, and Villanueva (2013), Capital Structure and Taxes: What Happens When You (Also) Subsidize Equity?, Unpublished Manuscript, Stanford University. 
Princen, S. (2012), Taxes do Affect Corporate Financing Decisions: The Case of Belgian ACE, CESifo Working Paper No. 3713. Munich.

Ruf, M., and Weichenrieder, A. (2012), The Taxation of Passive Foreign Investment Lessons from German Experience, Canadian Journal of Economics 45 (4), 1504-1528.

Sørensen P. B. (2014), Taxation and the Optimal Constraint on Corporate Debt Finance, CESifo Working Paper No. 5101.

Summers, L. H. (1987), Investments Incentives and Discounting of Depreciation Allowances, in Feldstein, M. (Ed.), The Effects of Taxation on Capital Accumulation, 295-304, University of Chicago Press, Chicago, IL.

Zangari, E. (2014), Addressing the Debt Bias: A Comparison between the Belgian and Italian ACE Systems, Taxation Working Paper No. 44-2014, European Commission, Brussels. 
Figure 1: Aggregate Equity Financed Lending of German firms in Belgium

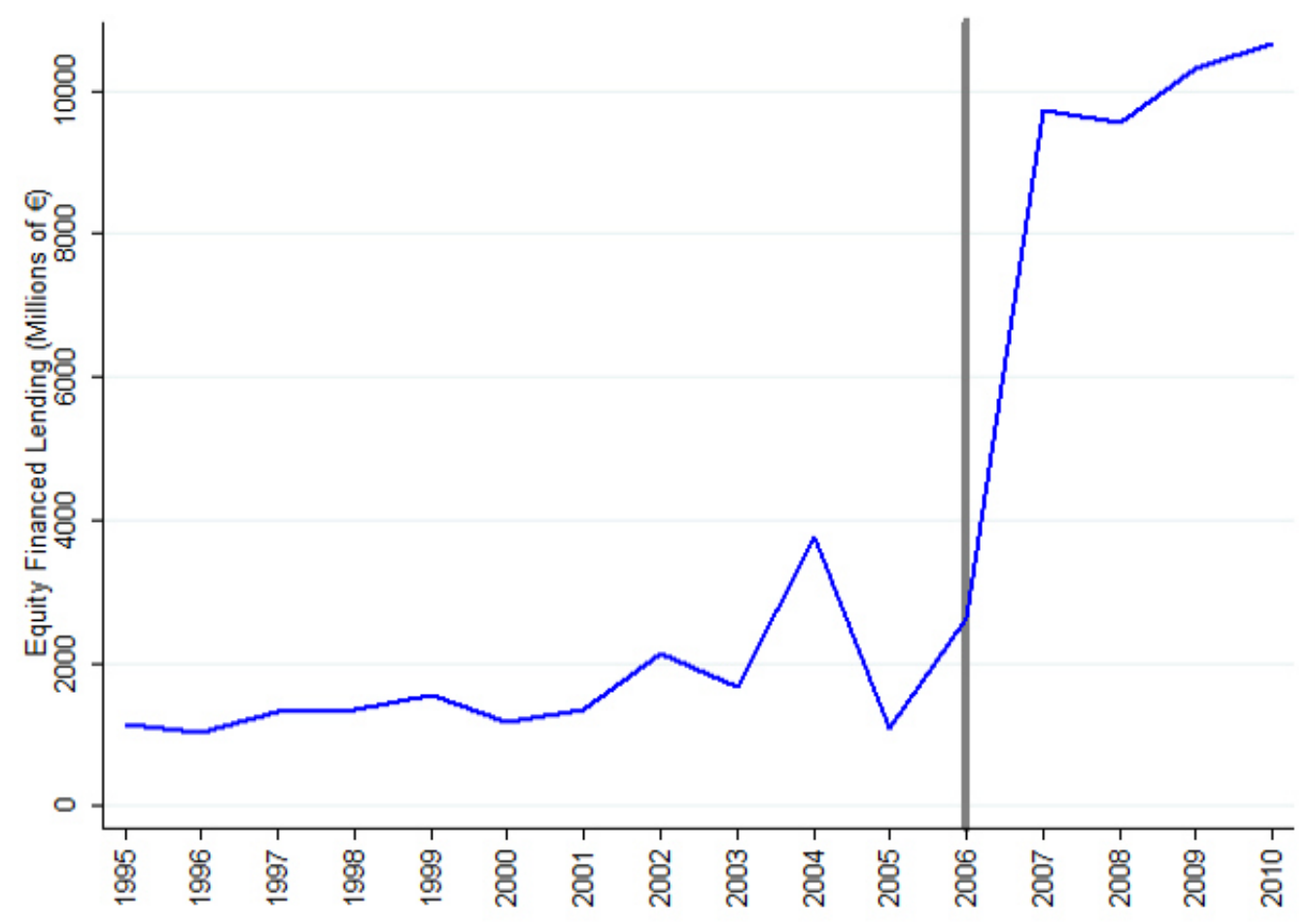

Note: The figure shows total equity-financed lending of German affiliates in Belgium defined as total loans to shareholders and affiliated enterprises with the German parent firm in a certain year minus total liabilities. Belgium implemented an ACE system in 2006. The source of the data is the MiDi database of the Deutsche Bundesbank. 
Figure 2: Average Debt Ratio

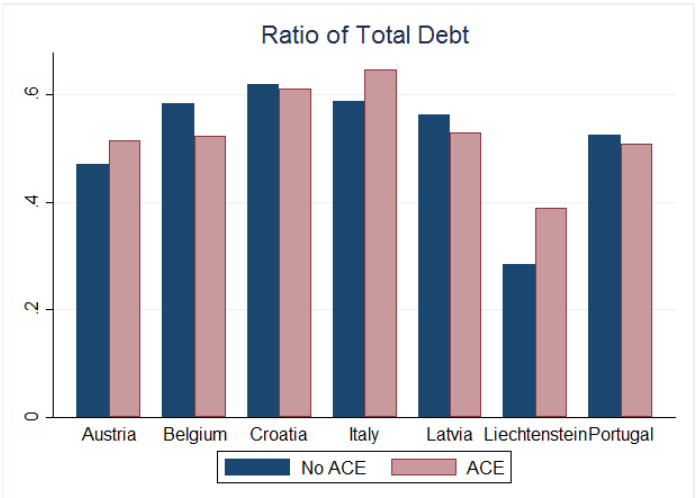

Note: The figure shows averages of total debt ratios of German affiliates in ACE countries. The source of the data is the MiDi database of the Deutsche Bundesbank. 
Figure 3: Debt Ratios and Statutory Corporate Income Tax Rates

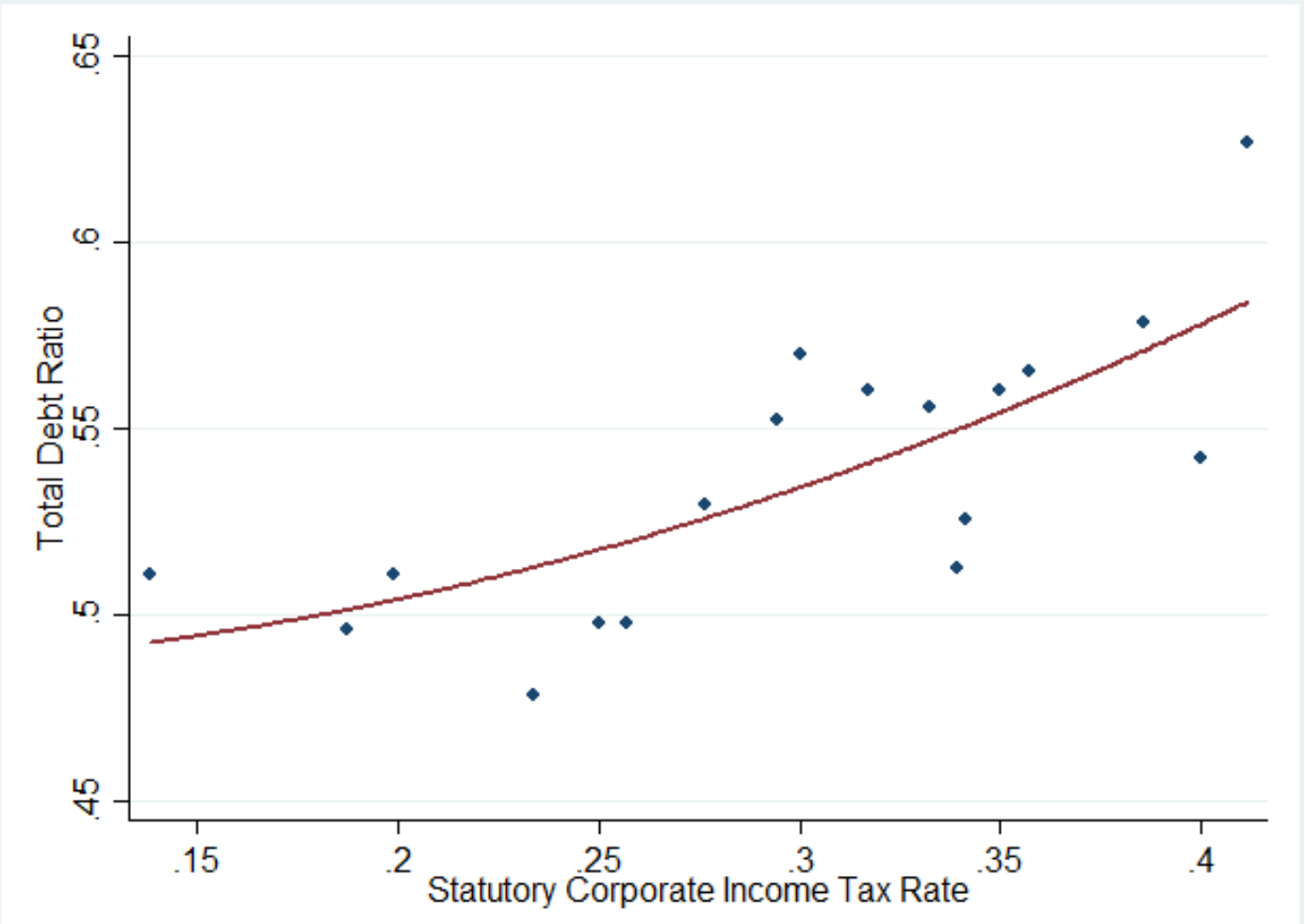

Note: This figure is a binned scatterplot of total debt ratios of German affiliates abroad and international statutory corporate income tax rates in the period 1999-2011. The source of the data on debt ratios is the MiDi database of the Deutsche Bundesbank. Salutatory corporate tax rates are collected by the authors as described in the text. 
Figure 4: Synthetic Control: Debt Financing

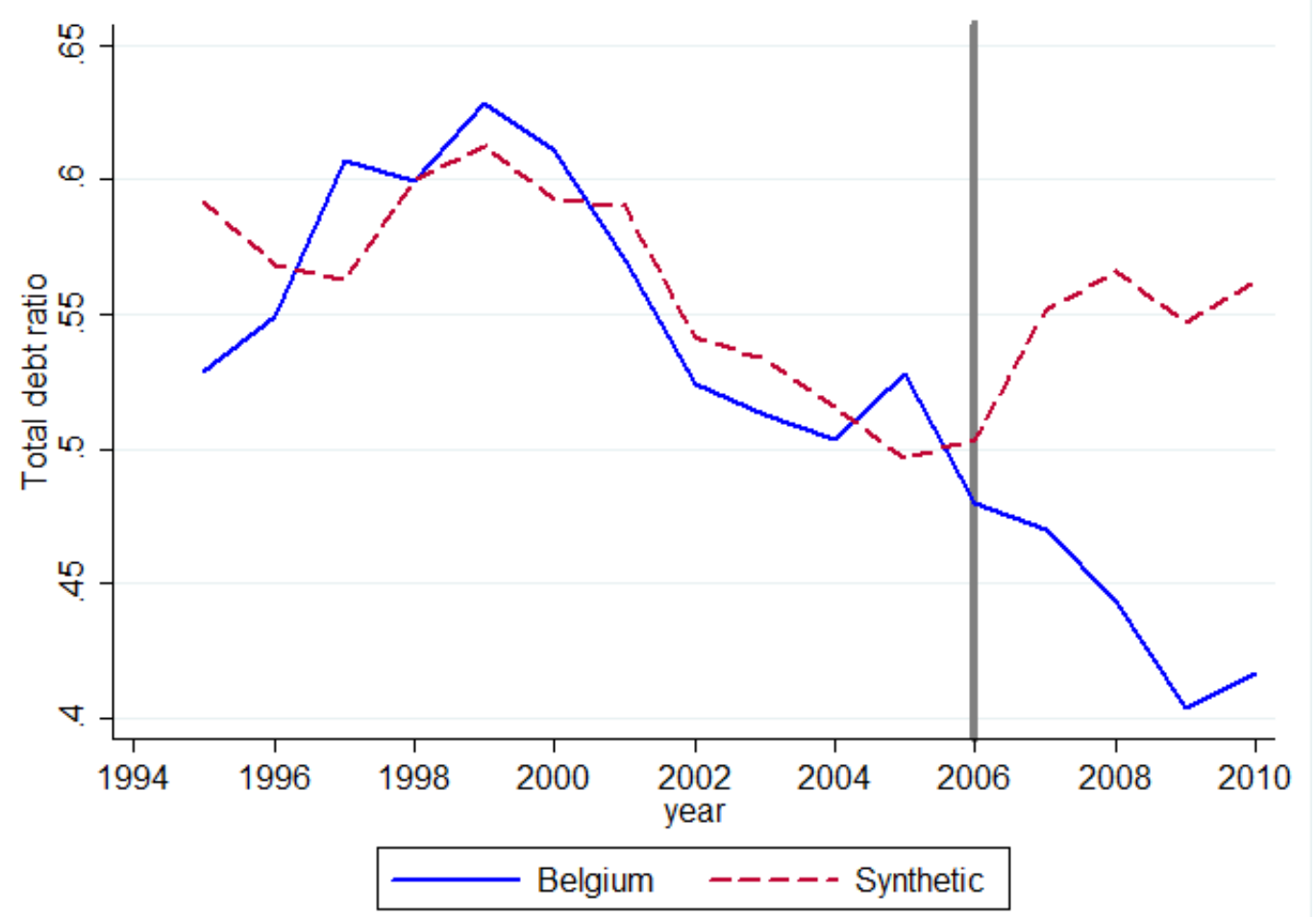

Note: The figure shows the average total debt ratio of German affiliates in Belgium. Belgium implemented an ACE system in 2006. Synthetic Belgium is obtained using synthetic controls methods as described in equation 3. The source of the data is the MiDi database of the Deutsche Bundesbank. 
Figure 5: Synthetic Control: Investments

(a) Passive Investment

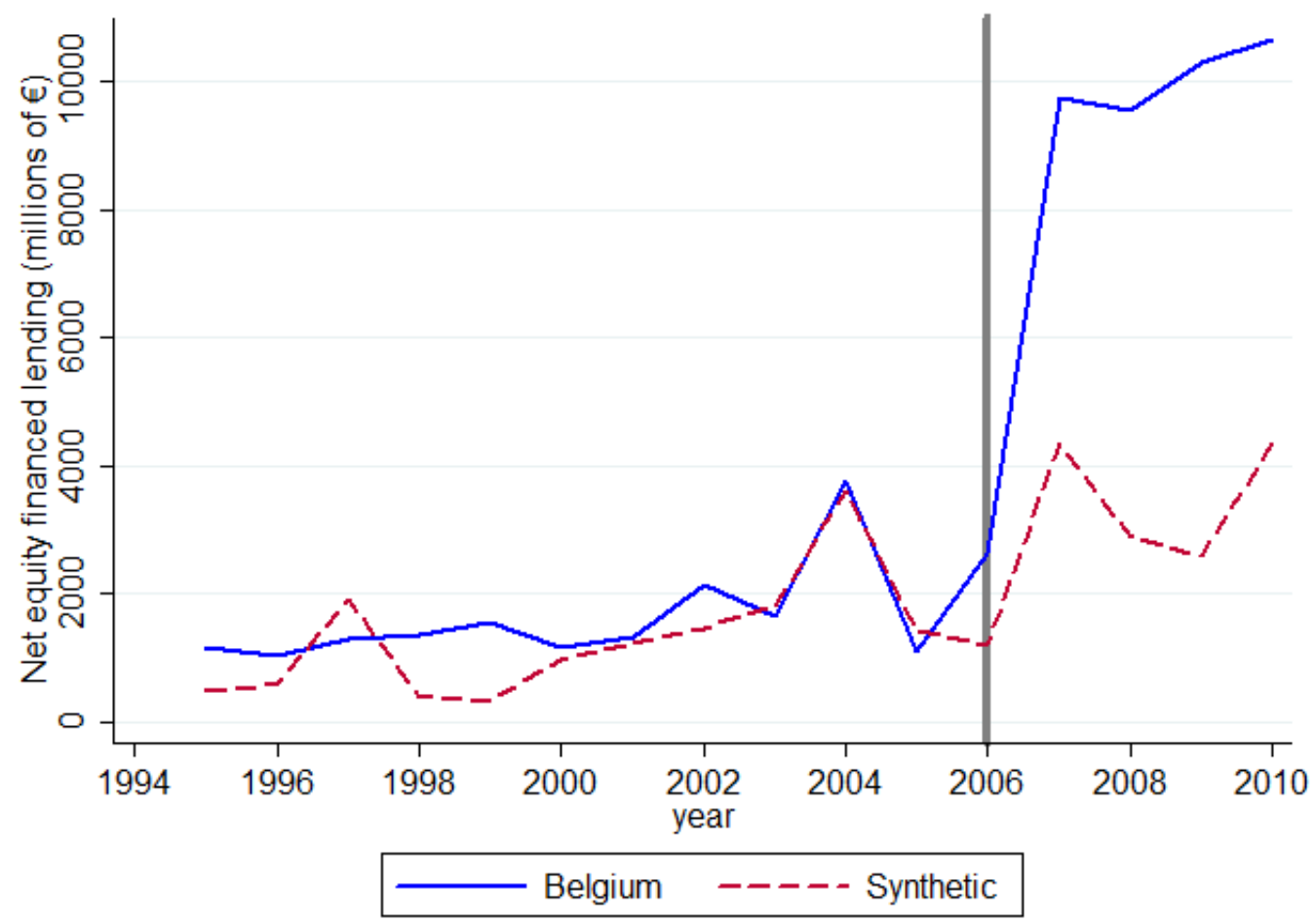

(b) Active Investment

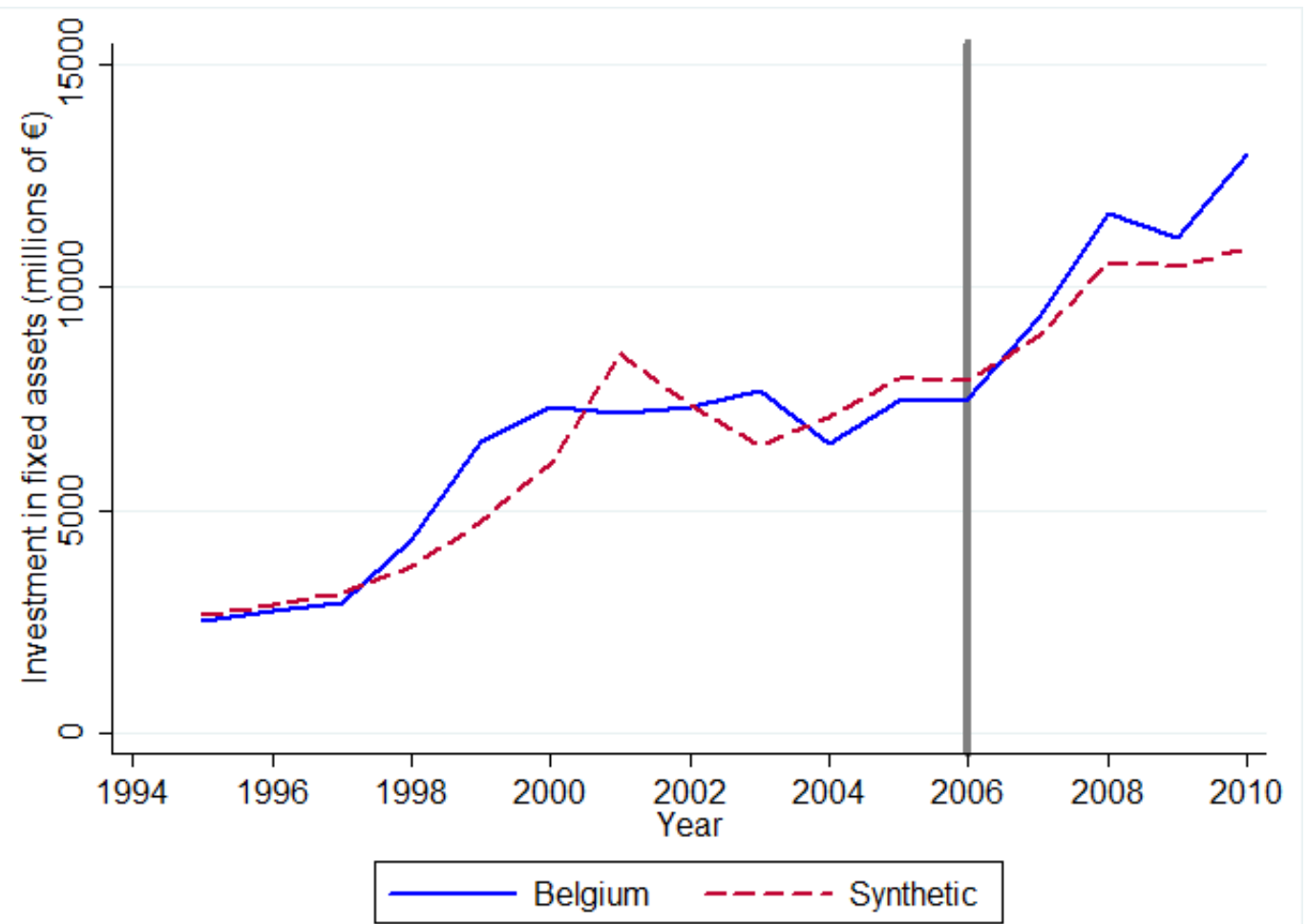

Note: The upper panel shows equity-financed lending of German affiliates in Belgium defined as total loans to shareholders and affiliated enterprises with the German parent firm in a certain year minus total liabilities. The lower panel shows active investment defined as total tangible and intangible assets. Belgium implemented an ACE system in 2006. Synthetic Belgium is obtained using synthetic controls methods as described in equation 3. The source of the data is the MiDi database of the Deutsche Bundesbank. 
Figure 6: Placebo Tests

(a) Passive Investment

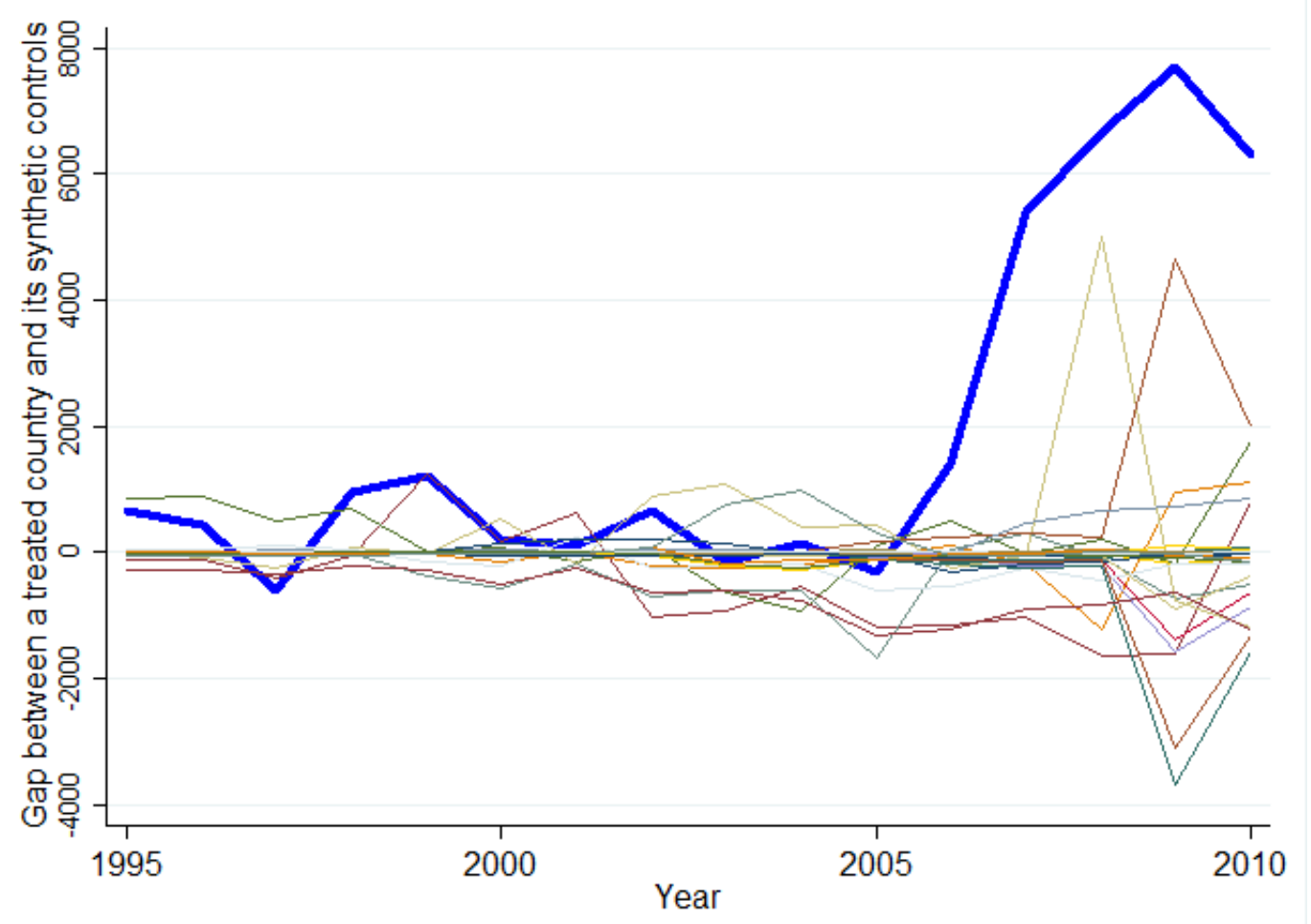

(b) Total Debt

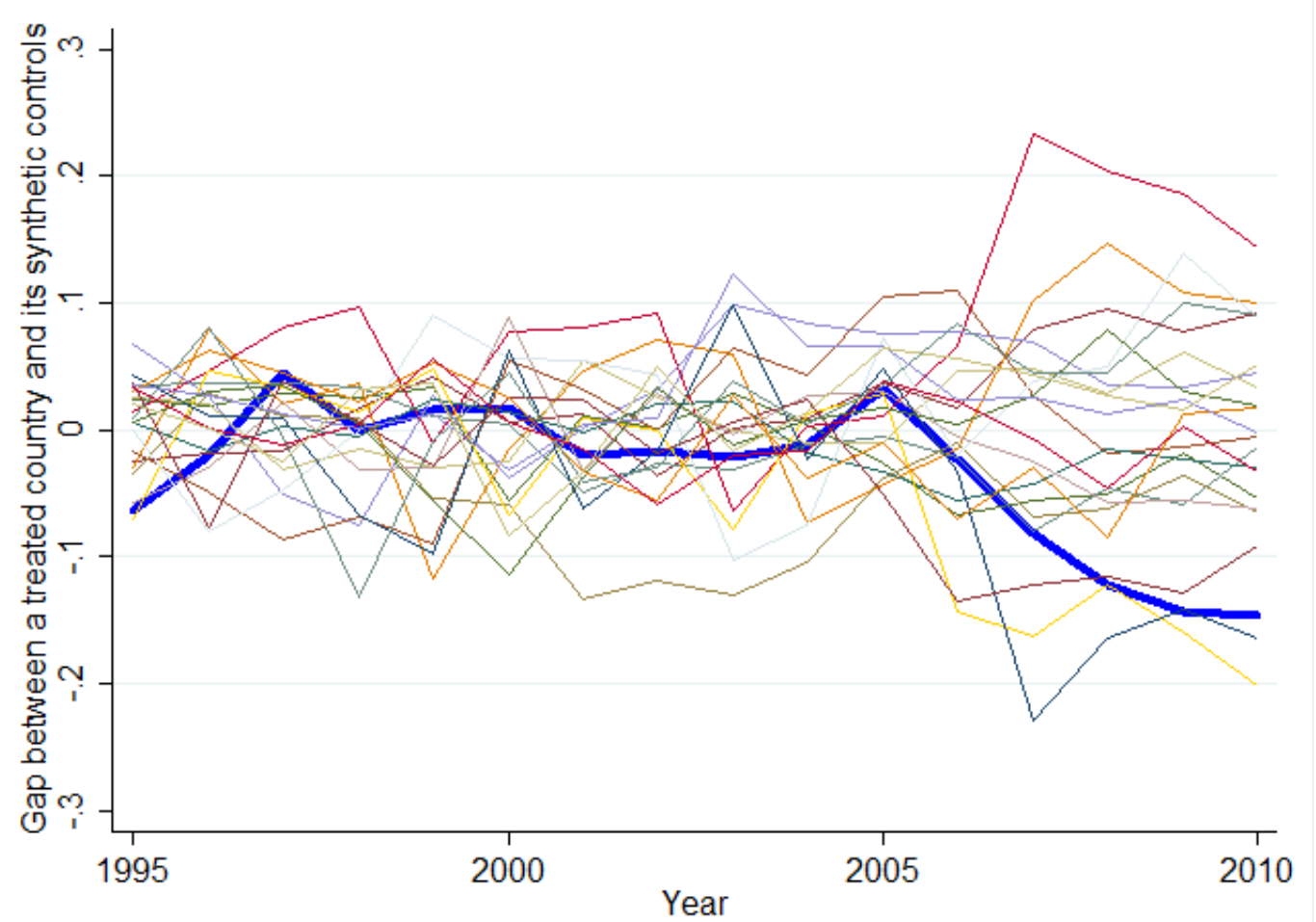

Note: This figures presents a series of placebo tests. The upper panel plots the gap between a control country and its synthetic for the variable equity-financed net lending. The lower panel plots the gap for the total debt ratio. Belgium is indicated by the thick blue curve. 
Table 1: List of Countries with ACE Systems

\begin{tabular}{lll}
\hline Country & Period & Type \\
\hline Austria & $2000-2004$ & Soft \\
Belgium & Since 2006 & Hard \\
Brazil & Since 1996 & Soft \\
Croatia & $1994-2000$ & Hard \\
Italy & $1997-2003$ & Soft \\
& Since 2012 & Soft \\
Latvia & $2009-2014$ & Soft \\
Liechtenstein & Since 2011 & Hard \\
Portugal & $2010-2013$ & Soft \\
Switzerland & Implementation within & Soft \\
& the next 5 years & \\
\hline
\end{tabular}

Note: This table lists countries that adopted an ACE system. A hard ACE regime considers the entire book value of equity as the base for computing the allowances, whereas a soft ACE regime treats only new (incremental) equity as the ACE base. Table A1 in the appendix provides additional details. 
Table 2: Benchmark Results: Total Debt and ACE Systems

\begin{tabular}{|c|c|c|c|c|c|c|c|}
\hline \multicolumn{8}{|c|}{ The dependent variable is the total debt ratio } \\
\hline & $(1)$ & $(2)$ & $(3)$ & $(4)$ & $(5)$ & $(6)$ & $(7)$ \\
\hline$A C E$ all & $\begin{array}{c}-0.035^{* * *} \\
(0.009)\end{array}$ & & & $\begin{array}{c}-0.013^{* * *} \\
(0.005)\end{array}$ & & & \\
\hline$A C E$ hard & & $\begin{array}{c}-0.050^{* * *} \\
(0.007)\end{array}$ & & & $\begin{array}{c}-0.038^{* * *} \\
(0.007)\end{array}$ & & $\begin{array}{c}-0.038^{* * *} \\
(0.007)\end{array}$ \\
\hline$A C E$ soft & & & $\begin{array}{c}-0.025^{* *} \\
(0.012)\end{array}$ & & & $\begin{array}{l}-0.005 \\
(0.005)\end{array}$ & $\begin{array}{l}-0.005 \\
(0.005)\end{array}$ \\
\hline Tax & $\begin{array}{c}0.347^{* * *} \\
(0.028)\end{array}$ & $\begin{array}{c}0.333^{* * *} \\
(0.028)\end{array}$ & $\begin{array}{c}0.329 * * * \\
(0.029)\end{array}$ & $\begin{array}{c}0.313^{* * *} \\
(0.056)\end{array}$ & $\begin{array}{c}0.295 * * * \\
(0.054)\end{array}$ & $\begin{array}{c}0.296^{* * *} \\
(0.058)\end{array}$ & $\begin{array}{c}0.305^{* * *} \\
(0.057)\end{array}$ \\
\hline Profitability & $\begin{array}{c}0.009 * * * \\
(0.002)\end{array}$ & $\begin{array}{c}0.009 * * * \\
(0.002)\end{array}$ & $\begin{array}{c}0.009^{* * *} \\
(0.002)\end{array}$ & $\begin{array}{c}0.006^{* * *} \\
(0.001)\end{array}$ & $\begin{array}{c}0.006^{* * *} \\
(0.001)\end{array}$ & $\begin{array}{c}0.00570 * * * \\
(0.001)\end{array}$ & $\begin{array}{c}0.006^{* * *} \\
(0.001)\end{array}$ \\
\hline Size & $\begin{array}{l}-0.001 \\
(0.000)\end{array}$ & $\begin{array}{l}-0.001 \\
(0.000)\end{array}$ & $\begin{array}{l}-0.001 \\
(0.000)\end{array}$ & $\begin{array}{c}0.030^{* * *} \\
(0.002)\end{array}$ & $\begin{array}{c}0.030^{* * *} \\
(0.002)\end{array}$ & $\begin{array}{c}0.030^{* * *} \\
(0.002)\end{array}$ & $\begin{array}{c}0.030 * * * \\
(0.002)\end{array}$ \\
\hline Tangibility & $\begin{array}{c}0.054^{* * *} \\
(0.006)\end{array}$ & $\begin{array}{c}0.054^{* * * *} \\
(0.006)\end{array}$ & $\begin{array}{c}0.055^{* * *} \\
(0.006)\end{array}$ & $\begin{array}{c}0.095^{* * * *} \\
(0.008)\end{array}$ & $\begin{array}{c}0.094^{* * *} \\
(0.008)\end{array}$ & $\begin{array}{c}0.095^{* * *} \\
(0.008)\end{array}$ & $\begin{array}{c}0.094^{* * *} \\
(0.008)\end{array}$ \\
\hline Industry leverage & $\begin{array}{c}0.439 * * * \\
(0.010)\end{array}$ & $\begin{array}{c}0.440^{* * *} \\
(0.010)\end{array}$ & $\begin{array}{c}0.439^{* * *} \\
(0.010)\end{array}$ & $\begin{array}{c}0.144^{* * *} \\
(0.012)\end{array}$ & $\begin{array}{c}0.144^{* * *} \\
(0.012)\end{array}$ & $\begin{array}{c}0.144^{* * *} \\
(0.012)\end{array}$ & $\begin{array}{c}0.144^{* * *} \\
(0.012)\end{array}$ \\
\hline Inflation & $\begin{array}{l}-0.000 \\
(0.000)\end{array}$ & $\begin{array}{l}-0.000 \\
(0.000)\end{array}$ & $\begin{array}{l}-0.000 \\
(0.000)\end{array}$ & $\begin{array}{c}0.000 \\
(0.000)\end{array}$ & $\begin{array}{c}0.000 \\
(0.000)\end{array}$ & $\begin{array}{c}0.000 \\
(0.000)\end{array}$ & $\begin{array}{c}0.000 \\
(0.000)\end{array}$ \\
\hline Growth & $\begin{array}{c}-0.001^{*} \\
(0.000)\end{array}$ & $\begin{array}{l}-0.001 \\
(0.000)\end{array}$ & $\begin{array}{c}-0.001^{*} \\
(0.000)\end{array}$ & $\begin{array}{c}-0.001^{* * *} \\
(0.000)\end{array}$ & $\begin{array}{c}-0.001^{* * *} \\
(0.000)\end{array}$ & $\begin{array}{c}-0.001^{* * *} \\
(0.000)\end{array}$ & $\begin{array}{c}-0.001^{* * *} \\
(0.000)\end{array}$ \\
\hline Political stability & $\begin{array}{c}-0.032^{* * *} \\
(0.003)\end{array}$ & $\begin{array}{c}-0.033^{* * *} \\
(0.003)\end{array}$ & $\begin{array}{c}-0.034^{* * *} \\
(0.003)\end{array}$ & $\begin{array}{c}-0.027^{* * *} \\
(0.005)\end{array}$ & $\begin{array}{c}-0.027^{* * *} \\
(0.005)\end{array}$ & $\begin{array}{c}-0.026^{* * *} \\
(0.005)\end{array}$ & $\begin{array}{c}-0.027^{* * *} \\
(0.005)\end{array}$ \\
\hline Interest & $\begin{array}{c}0.002 \\
(0.002)\end{array}$ & $\begin{array}{l}-0.001 \\
(0.003)\end{array}$ & $\begin{array}{c}0.000 \\
(0.003)\end{array}$ & $\begin{array}{l}-0.003 \\
(0.002)\end{array}$ & $\begin{array}{l}-0.003 \\
(0.002)\end{array}$ & $\begin{array}{l}-0.004 \\
(0.002)\end{array}$ & $\begin{array}{l}-0.003 \\
(0.002)\end{array}$ \\
\hline Constant & $\begin{array}{c}0.213^{* * *} \\
(0.015)\end{array}$ & $\begin{array}{c}0.220^{* * * *} \\
(0.015)\end{array}$ & $\begin{array}{c}0.220 * * * \\
(0.015)\end{array}$ & $\begin{array}{l}0.0264 \\
(0.031)\end{array}$ & $\begin{array}{l}0.0310 \\
(0.031)\end{array}$ & $\begin{array}{c}0.030 \\
(0.031)\end{array}$ & $\begin{array}{c}0.028 \\
(0.031)\end{array}$ \\
\hline Observations & 208,573 & 208,573 & 208,573 & 208,573 & 208,573 & 208,573 & 208,573 \\
\hline$R^{2}$ & 0.32 & 0.32 & 0.32 & 0.80 & 0.80 & 0.80 & 0.80 \\
\hline Affiliate FE & No & No & No & Yes & Yes & Yes & Yes \\
\hline Parent FE & Yes & Yes & Yes & No & No & No & No \\
\hline Year FE & Yes & Yes & Yes & Yes & Yes & Yes & Yes \\
\hline
\end{tabular}

Note: ${ }^{* * *} p<0.01, * * p<0.05,{ }^{*} p<0.1$. Robust standard errors are clustered at the country-year level, correcting for correlation of the errors within the cluster cell, and are reported in parentheses. The dependent variable is the ratio of liabilities to shareholders and other affiliated parties linked with the subsidiary to the total balance sheet. ACE all is a dummy equal to one if the host country adopts any ACE system and zero otherwise. ACE hard is a dummy equal to one if the host country adopts a hard ACE regime and zero otherwise. ACE soft is a tummy equal to one if the host country ants a soft ACE regime and zero otherwise. Tax is the international statutory corporate income tax rate. Profitability is the ratio of profit or loss for the financial year (after interest and taxes, prior to profit distribution, and offsetting tax rate. Profitability is the ratio of profit or loss for the financial year (after interest and taxes, prior to profit distribution, and offsetting
of losses carried forward) to shareholders' equity. Size is measured by the total balance sheet of the affiliate. Tangibility is the ratio of total tangible and intangible assets to total assets (including financial, current, and other assets). Industry leverage is an industry-specific variable defined as the median of the industry-specific leverage in each year. Inflation is the increase in consumer prices (annual \%) as provided by the World Bank WDI. Political stability is the political stability index of the World Bank Worldwide Governance Indicators; a higher value indicates higher stability. Interest is the log of the lending interest rate (\%) provided by the World Bank, complemented by the long-term interest rate provided by the OECD. $\mathrm{FE}=$ fixed effect. 
Table 3: Ratio of Loans from Affiliated Parties and ACE Systems

\begin{tabular}{|c|c|c|c|c|c|c|c|}
\hline \multicolumn{8}{|c|}{ The dependent variable is the ratio of loans from affiliated parties } \\
\hline & (1) & (2) & $(3)$ & (4) & $(5)$ & (6) & (7) \\
\hline ACE all & $\begin{array}{c}-0.028^{* * *} \\
(0.005)\end{array}$ & & & $\begin{array}{c}-0.016^{* * *} \\
(0.006)\end{array}$ & & & \\
\hline ACE hard & & $\begin{array}{c}-0.011^{* *} \\
(0.005)\end{array}$ & & & $\begin{array}{c}-0.012^{* *} \\
(0.006)\end{array}$ & & $\begin{array}{c}-0.012^{* *} \\
(0.006)\end{array}$ \\
\hline ACE soft & & & $\begin{array}{c}-0.0312^{* * *} \\
(0.006)\end{array}$ & & & $\begin{array}{c}-0.018^{* *} \\
(0.007)\end{array}$ & $\begin{array}{c}-0.018^{* *} \\
(0.007)\end{array}$ \\
\hline $\operatorname{Tax}$ & $\begin{array}{c}0.125^{* * *} \\
(0.028)\end{array}$ & $\begin{array}{c}0.104^{* * *} \\
(0.028)\end{array}$ & $\begin{array}{c}0.117^{* * *} \\
(0.028)\end{array}$ & $\begin{array}{l}0.099^{*} \\
(0.055)\end{array}$ & $\begin{array}{c}0.068 \\
(0.057)\end{array}$ & $\begin{array}{l}0.097^{*} \\
(0.055)\end{array}$ & $\begin{array}{l}0.101^{*} \\
(0.055)\end{array}$ \\
\hline Profitability & $\begin{array}{c}0.003^{* *} \\
(0.001)\end{array}$ & $\begin{array}{c}0.003^{* *} \\
(0.001)\end{array}$ & $\begin{array}{c}0.003^{* *} \\
(0.001)\end{array}$ & $\begin{array}{l}0.0007 \\
(0.001)\end{array}$ & $\begin{array}{l}0.0007 \\
(0.001)\end{array}$ & $\begin{array}{l}0.0008 \\
(0.001)\end{array}$ & $\begin{array}{l}0.0007 \\
(0.001)\end{array}$ \\
\hline Size & $\begin{array}{c}-0.007^{* * *} \\
(0.001)\end{array}$ & $\begin{array}{c}-0.007^{* * *} \\
(0.001)\end{array}$ & $\begin{array}{c}-0.007^{* * *} \\
(0.001)\end{array}$ & $\begin{array}{c}0.012^{* * *} \\
(0.002)\end{array}$ & $\begin{array}{c}0.012^{* * *} \\
(0.002)\end{array}$ & $\begin{array}{c}0.012^{* * *} \\
(0.002)\end{array}$ & $\begin{array}{c}0.012^{* * *} \\
(0.002)\end{array}$ \\
\hline Tangibility & $\begin{array}{c}0.014^{* * *} \\
(0.004)\end{array}$ & $\begin{array}{c}0.014^{* * *} \\
(.004)\end{array}$ & $\begin{array}{c}0.014^{* * *} \\
(.004)\end{array}$ & $\begin{array}{c}0.021^{* * *} \\
(0.0052)\end{array}$ & $\begin{array}{c}0.021^{* * *} \\
(0.0052)\end{array}$ & $\begin{array}{c}0.021^{* * *} \\
(0.0052)\end{array}$ & $\begin{array}{c}0.021^{* * *} \\
(0.0052)\end{array}$ \\
\hline Industry leverage & $\begin{array}{c}0.058^{* * *} \\
(0.006)\end{array}$ & $\begin{array}{c}0.058^{* * *} \\
(0.006)\end{array}$ & $\begin{array}{c}0.058^{* * *} \\
(0.006)\end{array}$ & $\begin{array}{c}0.045^{* * *} \\
(0.012)\end{array}$ & $\begin{array}{c}0.045^{* * *} \\
(0.012)\end{array}$ & $\begin{array}{c}0.045^{* * *} \\
(0.012)\end{array}$ & $\begin{array}{c}0.045^{* * *} \\
(0.012)\end{array}$ \\
\hline Inflation & $\begin{array}{c}0.000 \\
(0.000)\end{array}$ & $\begin{array}{c}0.000 \\
(0.000)\end{array}$ & $\begin{array}{c}0.000 \\
(0.000)\end{array}$ & $\begin{array}{c}0.001^{* *} \\
(0.000)\end{array}$ & $\begin{array}{c}0.001^{* *} \\
(0.000)\end{array}$ & $\begin{array}{c}0.001^{* *} \\
(0.000)\end{array}$ & $\begin{array}{c}0.001^{* *} \\
(0.000)\end{array}$ \\
\hline Growth & $\begin{array}{c}0.000 \\
(0.0004)\end{array}$ & $\begin{array}{c}0.000 \\
(0.0004)\end{array}$ & $\begin{array}{c}0.000 \\
(0.0004)\end{array}$ & $\begin{array}{c}-0.0001 \\
(0.000)\end{array}$ & $\begin{array}{c}-0.0001 \\
(0.000)\end{array}$ & $\begin{array}{c}-0.0001 \\
(0.000)\end{array}$ & $\begin{array}{c}-0.0001 \\
(0.000)\end{array}$ \\
\hline Political stability & $\begin{array}{c}-0.006^{* *} \\
(0.002)\end{array}$ & $\begin{array}{c}-0.007^{* * *} \\
(0.002)\end{array}$ & $\begin{array}{c}-0.007^{* * *} \\
(0.002)\end{array}$ & $\begin{array}{c}-0.0099^{*} \\
(0.006)\end{array}$ & $\begin{array}{l}-0.008 \\
(0.006)\end{array}$ & $\begin{array}{l}-0.009 \\
(0.006)\end{array}$ & $\begin{array}{c}-0.0099^{*} \\
(0.006)\end{array}$ \\
\hline Interest & $\begin{array}{c}0.004^{* *} \\
(0.002)\end{array}$ & $\begin{array}{c}0.000 \\
(0.002)\end{array}$ & $\begin{array}{c}0.003^{* *} \\
(0.002)\end{array}$ & $\begin{array}{c}0.012^{* * *} \\
(0.003)\end{array}$ & $\begin{array}{c}0.011^{* * *} \\
(0.003)\end{array}$ & $\begin{array}{c}0.011^{* * *} \\
(0.003)\end{array}$ & $\begin{array}{c}0.012^{* * *} \\
(0.003)\end{array}$ \\
\hline Constant & $\begin{array}{c}0.005 \\
(0.015)\end{array}$ & $\begin{array}{c}0.015 \\
(0.015)\end{array}$ & $\begin{array}{c}0.008 \\
(0.015)\end{array}$ & $\begin{array}{c}-0.178^{* * *} \\
(0.026)\end{array}$ & $\begin{array}{c}-0.171^{* * *} \\
(0.027)\end{array}$ & $\begin{array}{c}-0.178^{* * *} \\
(0.026)\end{array}$ & $\begin{array}{c}-0.178^{* * *} \\
(0.026)\end{array}$ \\
\hline Observations & 208,573 & 208,573 & 208,573 & 208,573 & 208,573 & 208,573 & 208,573 \\
\hline$R^{2}$ & 0.37 & 0.36 & 0.36 & 0.67 & 0.67 & 0.67 & 0.67 \\
\hline Affiliate FE & No & No & No & Yes & Yes & Yes & Yes \\
\hline Parent FE & Yes & Yes & Yes & No & No & No & No \\
\hline Year FE & Yes & Yes & Yes & Yes & Yes & Yes & Yes \\
\hline
\end{tabular}

Note: $* * * p<0.01,{ }^{* *} p<0.05, * p<0.1$. Robust standard errors are clustered at the country-year level, correcting for correlation of the errors within the cluster cell, and are reported in parentheses. The dependent variable is the ratio of liabilities to shareholders and other affiliated parties linked with the subsidiary to the total balance sheet. ACE all is a dummy equal to one if the host country adopts any ACE system and zero otherwise. ACE hard is a dummy equal to one if the host country adopts a hard ACE regime and zero otherwise. ACE soft is a dummy equal to one if the host country adopts a soft ACE regime and zero otherwise. Tax is the international statutory corporate income tax rate. Profitability is the ratio of profit or loss for the financial year (after interest and taxes, prior to profit distribution, and offsetting of losses carried forward) to shareholders' equity. Size is measured by the total balance sheet of the affiliate. Tangibility is the ratio of total tangible and intangible assets to total assets (including financial, current, and other assets). Industry leverage is an industry-specific variable defined as the median of the industry-specific leverage in each year. Inflation is the increase in consumer prices (annual \%) as provided by the World Bank WDI. Political stability is the political stability index of the World Bank Worldwide Governance Indicators; a higher value the World Bank WDI. Political stability is the political stability index of the World Bank Worldwide Governance Indicators; a higher value
indicates higher stability. Interest is the log of the lending interest rate (\%) provided by the World Bank, complemented by the long-term interest rate provided by the OECD. 
Table 4: Robustness

\begin{tabular}{l|r|r|rr}
\hline & \multicolumn{4}{|c}{ Specification with } \\
\hline Regression Including & $A C E$ all & $A C E$ hard & ACE hard and ACE soft \\
\hline Lagged explanatory variables & $-0.011^{* *}$ & $-0.039^{* * *}$ & $-0.039^{* * *}$ & -0.002 \\
& $(0.005)$ & $(0.005)$ & $(0.004)$ & $(0.005)$ \\
& $N: 165,333$ & $N: 165,333$ & $N: 165,333$ \\
& $R^{2}: 0.770$ & $R^{2}: 0.770$ & $R^{2}: 0.770$ \\
\hline Lagged dependent variable & $-0.006^{* * *}$ & $-0.018^{* * *}$ & $-0.018^{* * * *}$ & -0.003 \\
& $(0.002)$ & $(0.003)$ & $(0.003)$ & $(0.002)$ \\
& $N: 165,333$ & $N: 165,333$ & $N: 165,333$ \\
& $R^{2}: 0.839$ & $R^{2}: 0.839$ & $R^{2}: 0.839$ \\
\hline Highly profitable affiliates & $-0.017^{* * *}$ & $-0.027^{* * *}$ & $-0.027^{* * *}$ & $-0.014^{* *}$ \\
& $(0.005)$ & $(0.007)$ & $(0.007)$ & $(0.006)$ \\
& $N: 104,719$ & $N: 104,719$ & $N: 104,719$ \\
& $R^{2}: 0.751$ & $R^{2}: 0.751$ & $R^{2}: 0.751$ \\
\hline Less profitable affiliates & -0.008 & $-0.049^{* * *}$ & $-0.049^{* * *}$ & 0.003 \\
& $(0.005)$ & $(0.009)$ & $(0.009)$ & $(0.005)$ \\
& $N: 103,846$ & $N: 103,846$ & $N: 103,846$ \\
& $R^{2}: 0.764$ & $R^{2}: 0.764$ & $R^{2}: 0.764$ \\
\hline Small affiliates & $-0.015^{* *}$ & $-0.019^{* *}$ & $-0.018^{* *}$ & $-0.014^{*}$ \\
& $(0.006)$ & $(0.008)$ & $(0.008)$ & $(0.008)$ \\
& $N: 104,155$ & $N: 104,155$ & $N: 104,155$ \\
& $R^{2}: 0.768$ & $R^{2}: 0.768$ & $R^{2}: 0.768$ \\
\hline & $-0.011^{* *}$ & $-0.058^{* * *}$ & $-0.058^{* * *}$ & 0.002 \\
& $(0.005)$ & $(0.011)$ & $(0.011)$ & $(0.004)$ \\
& $N: 104,406$ & $N: 104,406$ & $N: 104,406$ \\
& $R^{2}: 0.735$ & $R^{2}: 0.735$ & $R^{2}: 0.735$ \\
\hline
\end{tabular}

Note: $* * * p<0.01,{ }^{*} p<0.05,{ }^{*} p<0.1$. Robust standard errors are clustered at the country-year level, correcting for correlation of the errors within the cluster cell, and are reported in parentheses. The dependent variable is the ratio of total liabilities to total balance sheet. $A C E$ all is a dummy equal to one if the host country adopts any ACE system and zero otherwise. ACE hard is a dummy equal to one if the host country adopts a hard ACE regime and zero otherwise. ACE soft is a dummy equal to one if the host country adopts a soft ACE regime and zero otherwise. Larger firms are those that have total balance sheet exceeding the sample median. Small firms are those that have total balance sheet lower than the sample median. Highly profitable affiliates are those with profits exceeding the sample median. Less profitable firms are those with profits lower than the sample median. All regressions include all explanatory variables as in Tables 1 and 2 , as follows: Tax is the international statutory corporate income tax rate. Profitability is the ratio of profit or loss for the financial year (after interest and taxes, prior to profit distribution and offsetting of losses carried forward) to shareholders' equity. Size is measured by the total balance sheet of the affiliate. Tangibility is the ratio of total tangible and intangible assets to total assets (including financial, current, and other assets). Median industry leverage is an industry-specific variable defined as the median of the industry-specific leverage in each year. Inflation is the increase in consumer prices (annual \%) as provided by the World Bank WDI Political stability is the political stability index of the World Bank Worldwide Governance Indicators; a higher value indicates higher stability. Interest is the log of the lending interest rate (\%) provided by the World Bank, complemented by the long-term interest rate provided by the OECD. 


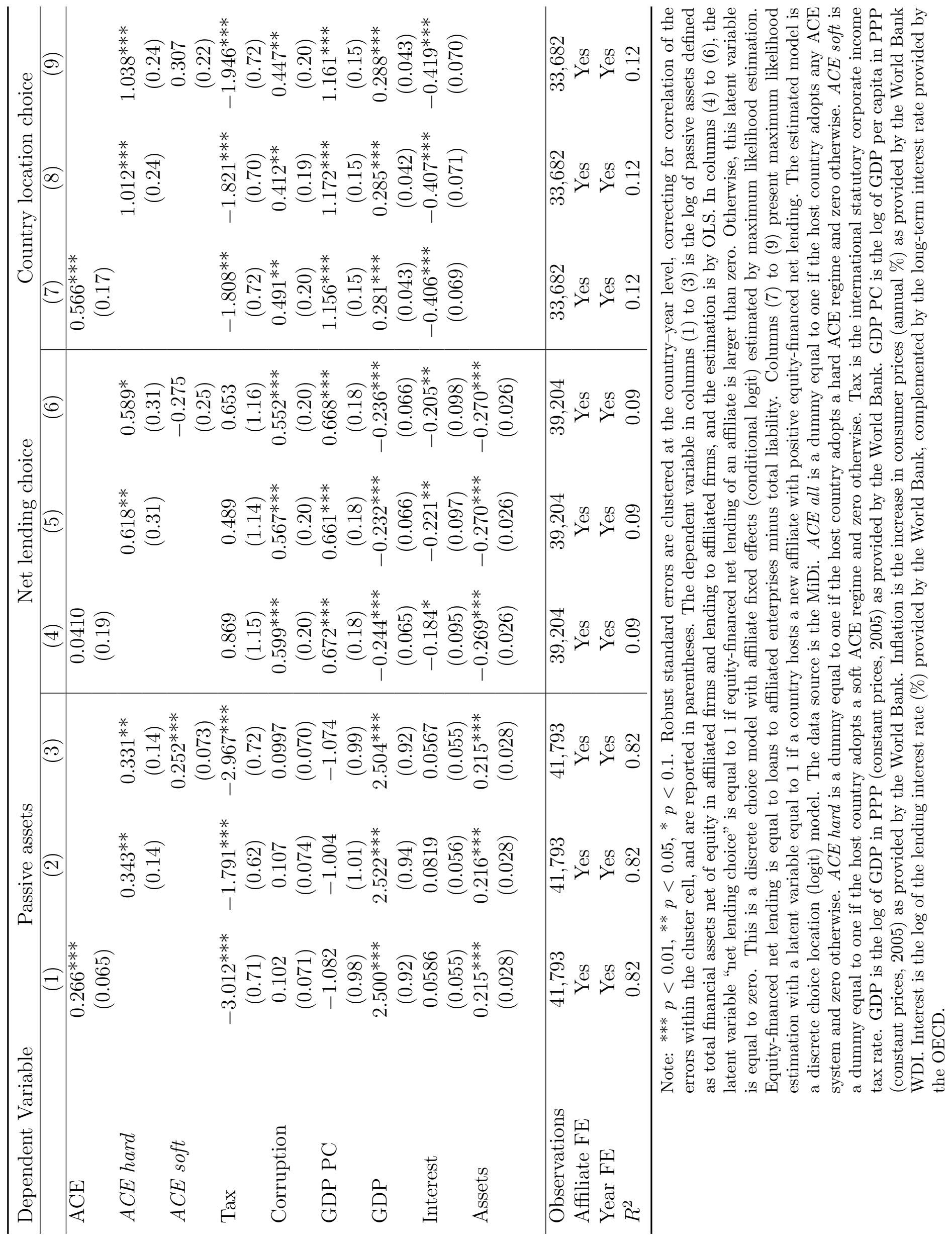


Table 6: Active Investment and ACE Regimes

\begin{tabular}{|c|c|c|c|c|}
\hline \multirow[t]{2}{*}{ Dependent Variable } & \multicolumn{4}{|c|}{ Log Fixed Assets } \\
\hline & (1) & $(2)$ & $(3)$ & (4) \\
\hline ACE all & $\begin{array}{l}0.0172 \\
(0.023)\end{array}$ & & & \\
\hline ACE hard & & $\begin{array}{c}-0.0603 \\
(0.039)\end{array}$ & $\begin{array}{c}-0.0626 \\
(0.039)\end{array}$ & $\begin{array}{c}-0.0646 \\
(0.042)\end{array}$ \\
\hline$A C E$ soft & & & $\begin{array}{l}0.0402 \\
(0.026)\end{array}$ & $\begin{array}{l}0.0369 \\
(0.027)\end{array}$ \\
\hline $\operatorname{Tax}$ & $\begin{array}{c}-1.164^{* * *} \\
(0.25)\end{array}$ & $\begin{array}{c}-1.127^{* * *} \\
(0.25)\end{array}$ & $\begin{array}{c}-1.196^{* * *} \\
(0.25)\end{array}$ & $\begin{array}{c}-1.088^{* * *} \\
(0.25)\end{array}$ \\
\hline GDP & $\begin{array}{c}0.316^{* * *} \\
(0.065)\end{array}$ & $\begin{array}{c}0.314^{* * *} \\
(0.065)\end{array}$ & $\begin{array}{c}0.313^{* * *} \\
(0.065)\end{array}$ & $\begin{array}{c}0.314^{* * *} \\
(0.055)\end{array}$ \\
\hline GDP PC & $\begin{array}{c}0.530^{* * * *} \\
(0.085)\end{array}$ & $\begin{array}{c}0.529 * * * \\
(0.085)\end{array}$ & $\begin{array}{c}0.514^{* * *} \\
(0.084)\end{array}$ & $\begin{array}{c}0.454^{* * *} \\
(0.076)\end{array}$ \\
\hline Unemployment & $\begin{array}{c}-0.178 * * * \\
(0.025)\end{array}$ & $\begin{array}{c}-0.175^{* * *} \\
(0.025)\end{array}$ & $\begin{array}{c}-0.183^{* * *} \\
(0.025)\end{array}$ & $\begin{array}{c}-0.199 * * * \\
(0.029)\end{array}$ \\
\hline Inflation & $\begin{array}{c}-0.0168^{* * *} \\
(0.0032)\end{array}$ & $\begin{array}{c}-0.0168^{* * *} \\
(0.0031)\end{array}$ & $\begin{array}{c}-0.0168^{* * *} \\
(0.0031)\end{array}$ & $\begin{array}{c}-0.0128^{* * *} \\
(0.0024)\end{array}$ \\
\hline Interest rate & $\begin{array}{l}0.0400^{*} \\
(0.024)\end{array}$ & $\begin{array}{l}0.0435^{*} \\
(0.023)\end{array}$ & $\begin{array}{c}0.0419^{*} \\
(0.024)\end{array}$ & $\begin{array}{c}0.0336 \\
(0.026)\end{array}$ \\
\hline Profitability & $\begin{array}{c}-0.0312^{* * *} \\
(0.0039)\end{array}$ & $\begin{array}{c}-0.0312^{* * *} \\
(0.0039)\end{array}$ & $\begin{array}{c}-0.0312^{* * *} \\
(0.0039)\end{array}$ & $\begin{array}{c}-0.0111^{* * *} \\
(0.0040)\end{array}$ \\
\hline Sales & $\begin{array}{c}0.102^{* * *} \\
(0.0031)\end{array}$ & $\begin{array}{l}0.102^{* * *} \\
(0.0031)\end{array}$ & $\begin{array}{l}0.102^{* * *} \\
(0.0031)\end{array}$ & $\begin{array}{c}0.0581^{* * *} \\
(0.0032)\end{array}$ \\
\hline GDP Growth & $\begin{array}{c}-0.00797^{* * *} \\
(0.0029)\end{array}$ & $\begin{array}{c}-0.00781^{* * *} \\
(0.0029)\end{array}$ & $\begin{array}{c}-0.00774^{* * *} \\
(0.0029)\end{array}$ & $\begin{array}{l}0.00383 \\
(0.0030)\end{array}$ \\
\hline Corruption & $\begin{array}{l}0.0540 \\
(0.045)\end{array}$ & $\begin{array}{l}0.0578 \\
(0.045)\end{array}$ & $\begin{array}{l}0.0554 \\
(0.044)\end{array}$ & $\begin{array}{c}0.00164 \\
(0.027)\end{array}$ \\
\hline Observations & 207,259 & 207,259 & 207,259 & 167,006 \\
\hline Affiliate FE & Yes & Yes & Yes & Yes \\
\hline Year FE & Yes & Yes & Yes & Yes \\
\hline Lagged Controls & No & No & No & Yes \\
\hline$R^{2}$ & 0.91 & 0.91 & 0.91 & 0.91 \\
\hline
\end{tabular}

Note: $* * * p<0.01,{ }^{* *} p<0.05, * p<0.1$. Robust standard errors are clustered at the country-year level, correcting for correlation of the errors within the cluster cell, and are reported in parentheses. The dependent variable "fixed assets" is the natural logarithm of total fixed tangible and intangible assets. $A C E$ all is a dummy equal to one if the host country adopts any ACE system and zero otherwise. $A C E$ hard is a dummy equal to one if the host country adopts a hard ACE regime and zero otherwise. $A C E$ soft is a dummy equal to one if the host country adopts a soft ACE regime and zero otherwise. Tax is the international statutory corporate income tax rate. GDP is the log of host in PPP (constant prict 2005) a a GDP in PPP (constant prices, 2005 Inflation is the increase in consumer prices (annual \%) as provided by the World Bank WDI. Interest is the log of the lending interest rate (\%) provided by the World Bank, complemented by the long-term interest rate provided by the OECD. Profitability is the ratio of profit or loss for the financial year (after interest and taxes, prior to profit distribution and offsetting of losses carried forward) to shareholders equity. Sales is the log of annual turnover in thousands of euros, plus one. GDP growth (annual \%) is provided by the World Bank. Corruption is the log of the corruption perception index as provided by Transparency International; a higher value indicates less corruption. All regressions are estimated using OLS and include firm and year fixed effects as indicated. 
Table 7: Corporations vs. Non-corporations: A Difference-in-differences Approach

\begin{tabular}{lcc}
\hline \multicolumn{3}{l}{ (a) Debt Financing } \\
\hline Dependent variable & Total debt & Loans from affiliated parties \\
\hline$\beta$ & $-0.121^{* * *}$ & $-0.067^{*}$ \\
& $(0.03)$ & $(0.03)$ \\
\hline Observations & 6,457 & 6,457 \\
$R^{2}$ & 0.78 & 0.64 \\
& & \\
& (b) Passive Investment \\
\hline Dependent variable & Passive assets & Total financial assets \\
\hline$\beta$ & $0.428^{*}$ & $0.547^{* *}$ \\
& $(0.024)$ & $(0.024)$ \\
\hline Observations & 1,892 & 3,111 \\
$R^{2}$ & 0.82 & 0.84 \\
\hline
\end{tabular}

(c) Active Investment

\begin{tabular}{lcc}
\hline Dependent variable & Fixed assets & Growth of fixed assets \\
\hline$\beta$ & & \\
\hline Observations & 0.115 & -0.109 \\
$R^{2}$ & $(0.14)$ & $(0.14)$ \\
\hline
\end{tabular}

$\begin{array}{lrr}\text { Affiliate FE } & \text { Yes } & \text { Yes } \\ \text { Year FE } & \text { Yes } & \text { Yes }\end{array}$

Note: ${ }^{* * *} p<0.01,{ }^{* *} p<0.05,{ }^{*} p<0.1$. Robust standard errors are in parentheses.

The coefficient $\beta_{1}$ is the average treatment effect estimated using the following equation:

$$
y_{i t}=\beta_{0}+\beta_{1}\left(\text { incor }_{i} \times A C E_{t}\right)+\mathbf{\Phi}_{i}+\boldsymbol{\lambda}_{t}+\epsilon_{i t},
$$

where the dummy incor $_{i t}$ is equal to 1 if the affiliate is incorporated; zero otherwise. $A C E$ is a dummy equal to one in the period of the Belgian ACE; zero otherwise. The total debt ratio is the ratio of total liabilities to total balance sheet. The variable "loans from affiliated parties" is the ratio of liabilities to shareholders and other affiliated parties linked with the subsidiary to the total balance sheet. "Passive assets" is the log of financial assets excluding shares in affiliated enterprises and loans to shareholders. "Financial assets" is the log of financial assets. The variable "fixed assets" is the log of total tangible and intangible assets. "Growth of fixed assets" is the annual change in total tangible and intangible assets. The sample includes only affiliates in Belgium and spans from 1999 to 2011. The source of the data is the MiDi. 


\section{Appendix}

\section{Table A1: Overview: Countries' Experiences with ACE Reforms}

\begin{tabular}{|c|c|c|c|c|}
\hline Country & Period & Name & Base/Rate & Details \\
\hline Austria & $2000-2004$ & Notional interest & $\begin{array}{l}\text { Book value of new (post-reform) equity/ Average return of } \\
\text { government bonds in secondary markets plus } 0.8 \mathrm{pp}\end{array}$ & $\begin{array}{l}\text { The notional return is taxed at a reduced } \\
\text { rate of } 25 \text { percent instead of } 34 \text { percent. }\end{array}$ \\
\hline Belgium & Since 2006 & $\begin{array}{l}\text { Risk capital } \\
\text { deduction/ } \\
\text { notional } \\
\text { interest deduction }\end{array}$ & $\begin{array}{l}\text { Book value of equity/Average monthly government bond rate } \\
\text { of year preceding fiscal year by } 2 \text { years. Rate capped at } 6.5 \\
\text { percent and cannot change by more than } \\
1 \mathrm{pp} \text { from year to year. Special SME rate is } 0.5 \mathrm{pp} \text { higher. }\end{array}$ & The notional return is deductible. \\
\hline Brazil & Since 1996 & $\begin{array}{l}\text { Remuneration of } \\
\text { equity }\end{array}$ & Book value of equity/Rate applicable to long-term loans & $\begin{array}{l}\text { Up to the level of the notional return, } \\
\text { dividends can be paid as } \\
\text { "interest on equity". This is deductible for } \\
\text { all corporate income taxes and subject to } \\
\text { the usual withholding tax on interest. }\end{array}$ \\
\hline Croatia & 1994-2000 & Protective interest & $\begin{array}{l}\text { Book value of equity } / 5 \text { percent } \\
\text { plus inflation rate of industrial goods if positive. }\end{array}$ & The notional return is deductible. \\
\hline \multirow[t]{2}{*}{ Italy } & 1997-2003 & Dual income tax & $\begin{array}{l}\text { Book value of new (post-reform) equity. From 2000: } 120 \text { percent } \\
\text { of new equity. In 2001: } 140 \text { percent of new equity, then again } \\
100 \text { percent of new equity./7 percent 1997-2000, } \\
6 \text { percent } 2001\end{array}$ & $\begin{array}{l}\text { The notional return is taxed at a reduced } \\
\text { rate of } 19 \text { percent. Other profits are taxed } \\
\text { at } 37 \text { percent } \\
\text { ( } 34 \text { percent in 2003). Before } 2001 \text {, the } \\
\text { average tax must be at least } \\
27 \text { percent. }\end{array}$ \\
\hline & Since 2012 & $\begin{array}{l}\text { Notional interest } \\
\text { deduction (NID) }\end{array}$ & $\begin{array}{l}\text { New equity (the amount of increase in equity over a } 2010 \text { base } \\
\text { equity amount)/For the first three fiscal years (2011, 2012, 2013): } \\
3 \text { percent; } 4 \text { percent for the } 2014 \text { fiscal year; } 4.5 \text { percent for 2015; } \\
4.75 \% \text { 2016; for subsequent years the rate will be based on the } \\
\text { Italian public debt securities' average return and a risk factor and } \\
\text { will be annually set by the Minister of Finance. }\end{array}$ & $\begin{array}{l}\text { Italian resident companies and Italian } \\
\text { permanent establishments of non-resident } \\
\text { companies can deduct the NID (with certain } \\
\text { exclusions and deductions). } \\
\text { The new equity does not include any profits } \\
\text { from that year. It can be calculated based on } \\
\text { qualifying upward and downward equity } \\
\text { adjustments after } 2010 \text {. } \\
\text { It may not exceed the company's equity at } \\
\text { the end of the given fiscal year. }\end{array}$ \\
\hline Latvia & Since 2009 & $\begin{array}{l}\text { Notional interest } \\
\text { deduction }\end{array}$ & $\begin{array}{l}\text { Retained earnings/ The specified percentage is the weighted } \\
\text { average rate of interest on loans to non-financial enterprises } \\
\text { made in the current taxable period. } 5.05 \text { percent in 2010, } 4.37 \\
\text { percent in } 2011 .\end{array}$ & $\begin{array}{l}\text { The deduction is equal to the specified } \\
\text { percentage of the retained earnings of the } \\
\text { immediately preceding taxable period. }\end{array}$ \\
\hline Liechtenstein & Since 2011 & $\begin{array}{l}\text { Notional interest } \\
\text { deduction }\end{array}$ & $\begin{array}{l}\text { Modified equity/ The applicable interest rate is specified } \\
\text { annually, depending on the market development (currently: } 4 \\
\text { percent). }\end{array}$ & The notional return is deductible. \\
\hline Portugal & $\begin{array}{l}2010-2013 \\
\text { replacement } \\
\text { by } 2014\end{array}$ & $\begin{array}{l}\text { Notional interest } \\
\text { deduction }\end{array}$ & $\begin{array}{l}\text { Share contributions during } 2010 \text { until } 2013 \text { respectively the share } \\
\text { capital/SME's held by individuals, venture capital companies and } \\
\text { business angels can benefit for a three-year period from a } \\
\text { notional interest deduction of } 3 \text { percent on the amount of cash } \\
\text { contributions by shareholders to share capital made during } 2010 \\
\text { through 2013; from 2014, individual-owned micro, small and } \\
\text { medium-sized enterprises may deduct } 5 \text { percent of the } \\
\text { company's share capital for three years (limited to EUR 200,000). }\end{array}$ & The notional return is deductible. \\
\hline Switzerland & $\begin{array}{l}\text { Implementa- } \\
\text { tion within } \\
\text { the next } 5 \text { to } 7 \\
\text { years }\end{array}$ & $\begin{array}{l}\text { Notional interest } \\
\text { deduction }\end{array}$ & $\begin{array}{l}\text { Will be further discussed in the course of the Corporate Tax } \\
\text { Reform III. }\end{array}$ & $\begin{array}{l}\text { Introduction of new special tax regimes } \\
\text { compatible with the European Union and } \\
\text { the Organisation for Economic Cooperation } \\
\text { and Development requirements. }\end{array}$ \\
\hline
\end{tabular}

Note: The sources of information are: PwC European Tax Newsalert, Washington National Tax Services (WNTS) Publication (2012), p. 1-3; Deloitte International Tax: Italy Highlights 2014, p. 3; European Tax Handbook 2012, p. 508; ZEW Project for the EU Commission, TAXUD/2008/CC/099, Final Report (2012), p. A-4; EY Worldwide Corporate Tax Guide 2013/14, p. 752, 753; wC Worldwide Tax Summaries: Corporate Taxes 2013/14, p. 1926; KPMG, Unternehmenssteuerreform III: http://www.kpmg.com/ch/de/services/tax/corporatetax/seiten/swiss-corporate-tax-reform.aspx, retrieved 10/04/14; and Klemm (2007). 
Table A2: Summary of Variables

\begin{tabular}{|c|c|c|c|}
\hline Variable & Mean & SD & Description \\
\hline Ace all & 0.0724 & 0.25 & $\begin{array}{l}\text { A dummy equal to one if the host country adopts an ACE } \\
\text { regime and zero otherwise }\end{array}$ \\
\hline$A C E$ soft & 0.0543 & 0.22 & $\begin{array}{l}\text { A dummy equal to one if the host country adopts a hard ACE } \\
\text { regime and zero otherwise }\end{array}$ \\
\hline ACE hard & 0.0181 & 0.25 & $\begin{array}{l}\text { A dummy equal to one if the host country adopts a hard ACE } \\
\text { regime and zero otherwise }\end{array}$ \\
\hline Total debt & 0.53 & 0.34 & The ratio of total liabilities to total balance sheet \\
\hline Loans from affiliated parties & 0.162 & 0.264 & $\begin{array}{l}\text { The ratio of liabilities to shareholders and other affiliated parties } \\
\text { linked with the subsidiary to total balance sheets }\end{array}$ \\
\hline Passive assets & 4.971 & 2.813 & $\begin{array}{l}\text { The log of total financial assets net of equity in affiliated } \\
\text { firms and lending to affiliated firms }\end{array}$ \\
\hline Equity-financed net lending & 8.22 & 2.146 & $\begin{array}{l}\text { The log of total loans to shareholders and affiliated enterprises } \\
\text { with the German parent firm in a certain year minus total liabilities }\end{array}$ \\
\hline Net lending choice & 0.0535 & 0.22 & $\begin{array}{l}\text { A dummy equal to one if an affiliate is a net lender; i.e., } \\
\text { if net lending choice }>0\end{array}$ \\
\hline Country location choice & 0.0213 & 0.14 & A dummy equal to one if a country host a net lender affiliate \\
\hline Fixed assets & 7.583 & 2.205 & The log of total fixed tangible and intangible assets \\
\hline Size & 9.833 & 0.247 & The log of the total balance sheet of the affiliate \\
\hline Tangibility & 0.247 & 0.274 & $\begin{array}{l}\text { The ratio of total tangible and intangible assets total assets } \\
\text { including financial, current, and other assets }\end{array}$ \\
\hline Profitability & 0.09 & 0.609 & $\begin{array}{l}\text { Profits prior to profit distribution and offsetting of losses carried } \\
\text { forward divided by total equity (total balance sheet minus } \\
\text { total liabilities) }\end{array}$ \\
\hline Industry leverage & 0.512 & 0.149 & The median of industry-specific total debt ratio \\
\hline $\operatorname{Tax}$ & 0.294 & 0.071 & Statutory corporate income tax rates \\
\hline GDP Growth & 2.45 & 3.2 & Annual GDP growth from the WB WDI \\
\hline GDP Capita & 9.972 & 0.8 & The log of PPP GDP per capita, constant prices (2005) from the WDI \\
\hline GDP & 26.24 & 1.73 & The log of PPP GDP level from the WB WDI \\
\hline Interest rate & 1.65 & 0.67 & The lending interest rate (WDI) and the long-term interest rate (OECD) \\
\hline Inflation & 2.84 & 3.59 & Annual changes in consumer prices from the WDI \\
\hline Political stability & 0.547 & 0.62 & The Political Stability index of the Worldwide Governance Indicators \\
\hline Corruption & 1.64 & 0.44 & The corruption perception index from transparency international \\
\hline
\end{tabular}

